\title{
A IEST OF THE LAW OE ONE PRICE IN RETAIL BANKING
}

Alfre do Mlartin-oliver, Vicente Salas-Fumas. and Jesus Saurina.

Documentos de Trabajo.

N. 0530

baneodestaña

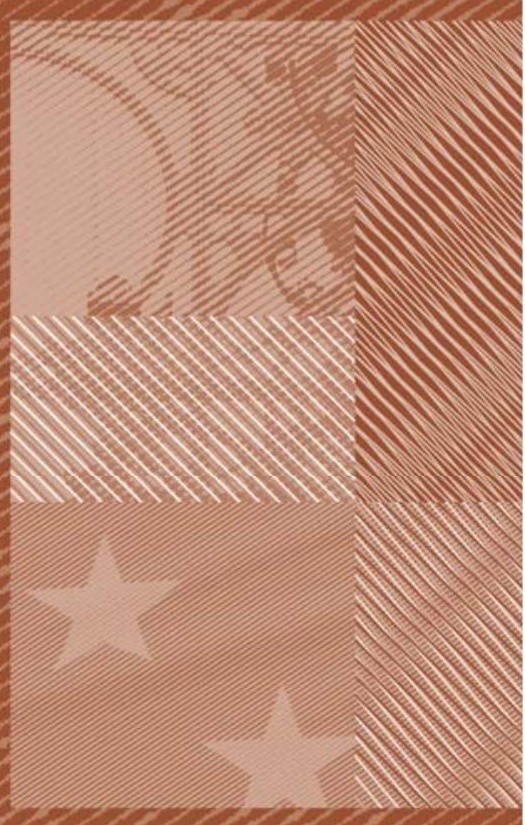


A TEST OF THE LAW OF ONE PRICE IN RETAIL BANKING 


\title{
A TEST OF THE LAW OF ONE PRICE IN RETAIL BANKING(*)
}

\author{
Alfredo Martín-Oliver \\ BANCO DE ESPAÑA \\ Vicente Salas-Fumás \\ UNIVERSIDAD DE ZARAGOZA AND BANCO DE ESPAÑA \\ Jesús Saurina ${ }^{(*)}$ \\ BANCO DE ESPAÑA
}

$\left.{ }^{*}\right)$ This paper is the sole responsibility of its authors and the views represented here do not necessarily reflect those of the Banco de España. We thank the very valuable comments of A. Novales as well as those of an anonymous referee and the Editor, F. Restoy, to a previous version of the paper.

(**) Address for correspondence: Jesús Saurina; c/ Alcalá, 48, 28014 Madrid, Spain. Phone: + 3491338 5080; e-mail: jsaurina@bde.es 
The Working Paper Series seeks to disseminate original research in economics and finance. All papers have been anonymously refereed. By publishing these papers, the Banco de España aims to contribute to economic analysis and, in particular, to knowledge of the Spanish economy and its international environment.

The opinions and analyses in the Working Paper Series are the responsibility of the authors and, therefore, do not necessarily coincide with those of the Banco de España or the Eurosystem.

The Banco de España disseminates its main reports and most of its publications via the INTERNET at the following website: http://www.bde.es.

Reproduction for educational and non-commercial purposes is permitted provided that the source is acknowledged.

\section{(c) BANCO DE ESPAÑA, Madrid, 2005}

ISSN: 0213-2710 (print)

ISSN: 1579-8666 (on line)

Depósito legal:

Imprenta del Banco de España 


\section{Abstract}

This paper investigates the level and determinants of retail banking interest rate differences among Spanish banks in the period 1989-2003. We find that interest rates of twenty five different bank loan and deposit products adjust rather rapidly to their long term values in response to external shocks, as the relative version of the Law of One Price predicts, but the evidence runs contrary to the absolute version of the Law. Different credit risk across banks and loan products is an important source of interest rate dispersion in the short and long run that puts limits to banking integration.

JEL: G21.

Key words: price dispersion, mark up convergence. 


\section{Introduction}

This paper uses Spanish retail banking as a case study to investigate the workings of the Law of One Price. The findings of convergence or divergence in interest rates of loans and deposits within a country member are important to shape expectations about the evolution of interest rate convergence in European banking after the introduction of the Euro. Although economic integration and price convergence has been a topic of interest in international economics $^{1}$ and there are several country level studies on price differentiation ${ }^{2}$, we are not aware of a comprehensive analysis of the Law of One Price in retail banking as the one presented in this paper.

We take advantage of a large and unique database: monthly quoted annual interest rates for twenty five different banking products and for each individual commercial and savings bank during the period 1989 to 2003. Thus, we have information about marginal interest rates for both, loan and deposit products. Combining different data sources we are able to obtain credit risk adjusted opportunity costs for each loan product at the bank level, so the convergence in gross profit margins as part of the convergence in interest rates is evaluated after controlling for the credit risk of each individual bank. Banks' products are grouped into loans and deposits. Loans have different maturity, from less than a month to very long term, such as mortgages. Deposits differ in liquidity, from the very liquid sight accounts to the more illiquid two-year deposits. The time period of study starts in 1989 when restrictions to geographic expansion of savings banks, now half of the market, were removed and banking liberalization completed. ${ }^{3}$ Between 1994 and 1998 Spain is in a process of nominal convergence to meet the Maastrich criteria in order to become a member of the Euro zone; nominal official interest rates fell from 15\% to 3.5\%. Over the 1999-2003 period, Spain has been a full member of the Euro zone. Thus, each time period offers a different scenario in terms of monetary and competitive conditions under which banks grant loans and receive deposits, which is worthwhile to study separately. The comparison of the results over time will provide evidence of the effects of the Euro in the creation of a single market for bank loan and deposit products at the country member level.

Interest rate differences will be evaluated under absolute and relative versions of the Law of One Price. The absolute version of the Law is violated when products that are close substitutes for the buyers sell at difference prices in a persistent way. Thus, the study of interest differences across banks and/or product classes in loans or deposits will indicate whether markets are integrated or not. But persistent interest rate differences can be possible because of, for example, idiosyncratic bank factors that cannot be arbitraged away. Then, market integration can be evaluated from the speed at which temporary deviations from the long-term across-banks interest differences are eliminated (i.e. the relative version of the Law of One Price).

The paper is in line with research on convergence of interest rates and evolution of market power in retail banking within the EU countries [see Baele et al. (2004) for an overview]. But with the advantage that we have very disaggregated data for practically the

1. Frankel and Rose (1996), Taylor (2002) offer general evidence on the workings of the Law of Purchasing Power Parity. Goldberg and Verboven (2001 and 2004) study price discrimination and price convergence in the European car market.

2. Cecchetti et al. (2002), Engel and Rogers (2001), Asplund and Friberg (2001).

3.Salas and Saurina (2003) analyses the Spanish banking liberalization process. 
whole industry (95\% of the loans and deposits), and a long period of time. Therefore, we can address questions such as the contribution to interest rate differentiation of time, bank, product and geographic market effects, not explored so far. Second, we can isolate the effects on the evolution of interest rate dispersion of changes in monetary conditions and changes in marginal opportunity costs of loans and marginal revenues from deposits. From the test of the relative version of the Law of One Price we are able to obtain the long term relative mark up over opportunity cost of loans and the relative mark down over revenue from deposits. Therefore, the analysis of interest rate dispersion also provides measures of market power of banks and their evolution over time. European banking integration is concerned about price dispersion together with market power [Bikker and Haaf (2002), Courvoisier and Gropp (2002), Maudos and Fernandez de Guevara (2004), Goddard et al. (2004)], and the paper contributes to this literature with a unified methodology and with evidence from product-bank marginal interest rates.

Papers on market power of European banks, Angelini and Cetorelli (2003) for Italy and Fernández de Guevara and Maudos (2004) for Spain, for example, all use bank level aggregated data and estimate margins and profits for loans over the marginal cost of inputs, including the cost of deposits. In this paper we estimate profit margins at the individual bank product level using current monthly quoted interest rates by each individual bank. Most published research in market power of banks with individual bank-product data has used interest rate of deposits, Berger and Hannan (1989), Hannan and Liang (1993), and little is known about the effect of credit risk premiums in the interest rate/gross margin at the product-bank level. One important limitation to study market power in loan markets is that credit risk premium data are difficult to find. Using Banco de España Credit Register database, we are able to compute bank and loan product level data on ex post credit risk that can be used to estimate the risk adjusted opportunity cost of the loans. Therefore, we provide risk adjusted long term mark up estimates for loans of different maturities. ${ }^{4}$

Since interest rates and cost data refer to a single country, the contribution to the evaluation of European banking integration is only indirect. One important result of this analysis is that banks' idiosyncratic effects are an important source of interest rate differentiation. Moreover, in loan products, the relative contribution of bank effects to differentiation increases over time. If the same pattern can be expected at supra national level, European cross country convergence in loan interest rates may not be the most appropriate benchmark to follow up the process of retail banking integration, unless all banks end up with similar credit risk in their portfolios. Second, we find that the (long term) Lerner index of loans, a conventional measure of market power, is substantially reduced when the marginal cost used in the computation of the index includes the credit risk premium of each bank-loan observation, which confirms the relevance of product and bank level variables to explain differences in interest rates.

The rest of the paper is organized as follows. Section 2 contains a description of the data and a preliminary evidence of interest rate differentiation in Spanish retail banking. Section 3 focuses on the absolute version of the Law of One Price through the evaluation of the contribution to dispersion in profit margins of sources of potential differentiation (Time, Bank, Product and Province). Section 4 presents a test of the relative version the Law of One Price and estimates of the long-term relative difference between interest rates and opportunity costs for each of the bank products. In section 5 we summarize the conclusions of the paper.

4. Jiménez and Saurina (2003) and Jiménez, Salas and Saurina (2004) also exploit Banco de España Credit register and contain a thorough description of it. 


\section{Description of the data and preliminary evidence on interest rate dispersion}

\subsection{Database}

Data on interest rates come from the confidential returns that Commercial and Savings banks send monthly to the Banco de España on interest rates for loan and deposit operations made during the previous month. The interest rate reported by a bank on a given product is the weighted average of equivalent annual interest rates set in all operations made in that product during the corresponding month. So, banks report actual (i.e. marginal) interest rates charged in the transactions. The raw data has been filtered to eliminate inactive banks and to assure a minimum number of annual observations for each bank and product.

Banks with tiny market share (less than 1 over 10,000 in terms of total assets) have been excluded from the analysis. Branches of foreign banks, which concentrate mainly in the wholesale market are also excluded, since our focus is on retail banking. Only bank-product combinations for which at least eight monthly observations are available within a year are selected; this should reduce the number of missing values from banks that have a reduced number of operations in a given product and year. Finally, to keep a manageable number of observations, monthly interest rates are averaged to quarterly. Thus, we have interest rate data on new loans and deposits made by around 200 different Spanish banks during 58 quarters for 25 different products (close to 300,000 observations).

The bank products, loans and deposits of different maturity and liquidity, included in the database are summarized in Table 1. There are five loan products and four deposit products. Among the former, discounting of Receivables and Credit Lines are loans granted to business firms and individual entrepreneurs, while Personal loans and Mortgages are granted to individuals and families. Loans at Variable Interest rate are granted to both. Mortgages have all long-term maturity (above 3 years) but the rest of loan products have different maturities. Loans are grouped by maturity: less than one month, from 1 to 3 months, from 3 months to 1 year, from 1 year to 3 years and more than 3 years. Deposit products include Current Accounts (sight deposits with check facilities), Saving accounts (sight deposits with no check facilities), Deposits and Repo type deposits (deposits backed by the bank with a government security debt instrument). Banks do not report Current and Saving Accounts that pay negligible interest rates. ${ }^{5}$ Current and Saving accounts are considered high liquidity products, while Deposits can be of high, medium or low liquidity depending on the reimbursement period (less than 3 months, from 3 months to 2 years and more than 2 years, respectively). Repo type products can be of medium liquidity, from 3 months to 2 years and of high liquidity, less than 3 months.

Banks in the database have two ownership forms. Commercial banks are for profit companies controlled by private shareholders. Savings banks are not for profit organizations under shared control and governance of representatives of public authorities (town and region), depositors, workers and founding institutions. At the end of the period the two ownership forms split evenly $95 \%$ of the Spanish retail banking market. ${ }^{6}$ Banks are also classified according to the geographical scope of their business as National (37\% of deposit share in 2002), when they have branches in $90 \%$ of the 50 Spanish provinces. Local (16\% of deposit share in 2002), when the bank concentrates $90 \%$ of the branches in a single

5. The $1^{\text {st }}$ percentile of the distribution of interest rates of these two products takes the value of $0.91 \%$.

6. The other $5 \%$ correspond to Credit Cooperatives that do not report interest rates to Banco de España. 
province, and Regional, all the rest. In late 1988, the last regulation that limited the geographical expansion of Savings banks was removed. Since then, Savings banks have been very active in opening branches outside their historical territories and, thus, increasing the number of competitors in local markets. As a consequence, province level market concentration has been stable over time in spite of the mergers of very large banks that have taken place during the period. ${ }^{7}$ In the paper merged banks are considered a new bank from the moment the merger occurs and separated institutions before it.

In retail banking, markets are local for most products and services. The information available on interest rates is not disaggregated enough to know the town or city where bank operations are made. Therefore, we do not know the interest rates in different geographic markets, except when the bank concentrates most of its business in a single province. In each province there are local and national banks operating through branches. We assume that a national bank sets the same interest rate of a particular product in all provinces where it operates. With this assumption and the observed interest rates charged by the local banks in the province we can test if Province markets contribute or not to interest rate differentiation.

\subsection{Preliminary evidence on interest rate levels and dispersion}

The evolution over time of interest rate levels for loan and deposit products are presented in Figure 1. Values shown are averages across all banks and maturities of each product in the corresponding quarter. It is clear that the driving force behind the decline in interest rates during the sample period has been the decline in official interest rates, represented in Figure 1 by the one-day interbank rate. In loan products, the absolute difference between the interest rates charged by banks and the interbank rate has been rather stable, while in deposits it was very high in the first part of the sample ant it is substantially reduced at the end of it. Figure 2 shows the evolution of the estimated coefficient of variation, a dispersion measure, for selected loan and deposit products across banks. In Mortgages dispersion stays stable over time since 1993, while for the other three products, Credit Line, Current Accounts and Deposits, interest rate dispersion across banks increases over time.

Taking all products, interest rate dispersion is represented by the histograms in Figure 3. The dispersion variable is the range of interest rates, defined as the differences between the values of the $90^{\text {th }}$ and the $10^{\text {th }}$ percentile of the distribution of interest rates across banks in each quarter, normalized by the average interest rate of the product. For the whole 1989-2003 time period, $25 \%$ of the bank quarterly observations showed a relative range of interest rates above $50 \%$. Dispersion seems to increase over time. In the 1989-1993 period, the relative range of interest rates was above $50 \%$ in only $15 \%$ of the bank quarterly observations, raising to $20 \%$ in $1994-1998$ and to $40 \%$ in the last five-year period. The separated histograms for loans and for deposits, not shown, confirm that dispersion increases over time in both type of bank products.

Information on level and dispersion of interest rates is summarized in Table 2. The rows under "Differentials" include, for all products, as well as separated for loans and deposits, the average difference between the interest rate and the one-day interbank rate both in quarter $t$, and also this average difference relative to the interest rate of the respective loan or deposit. "Dispersion Measures" shown are, average differences between the $90^{\text {th }}$ and $10^{\text {th }}$ interest rate percentiles in period $t$ divided by the average interest

7. The Herfindahl index of market concentration in total loans, average across the 50 provinces, has been stable around 0.10 
rate, and the average coefficients of variation from the distribution of interest rates in each quarter $t$. From this preliminary evidence, including histograms and the summary of Table 2, we conclude the following:

i) Average interbank interest rates are $13.66 \%$ in 1989-1993, $7.35 \%$ in 1994-1998 and $3.61 \%$ in $1999-2003$, evidence of the radical change in monetary conditions in Spain. In the same time intervals the average absolute differences between interest rates of loans and deposits with respect to the interbank rate (spreads) are, respectively, 2.98, 3.26, 2.76, and 4.16, 1.40, 0.81 percentage points. Thus, average absolute differences decline substantially more in deposits than in loans, where they remain quite stable over time.

ii) In relative terms, differences with the interbank rate increase over time in both, loans and deposits: from $17 \%$ in $1989-1993$ to $40 \%$ in $1999-2003$ for the former, and from $75 \%$ to $90 \%$ for the latter.

iii) Irrespectively of the measure of dispersion used, interest rate dispersion shows an increasing trend over time when all bank products are considered. Therefore, no evidence exists that interest rate dispersion decreases after the introduction of the Euro.

iv) Interest rate dispersion is in general higher for deposit than for loan products, especially during the 1989-1993 period. Since 1994, overall dispersion measures give similar values for the two groups of products, thus, a convergence in dispersion in the two markets is observed over time. 


\subsection{Why can interest rates differ?}

Loan markets are not homogeneous and banks offer different products to respond to different borrower needs and information conditions. In the database we have loans granted to business, like Receivable and Credit Line, and loans to individual persons and families, such as Personal and Mortgages. Within each product class, loans vary in maturity. Some are secured with external and others with internal collateral; some loans are made at fixed interest rates and others at variable rates, what means a different allocation of risks between borrower and lender. If loan products are different in several dimensions because they respond to different market needs, market equilibrium bank interest rates can differ across product classes and maturity. However, the demand for one class of loans will not be independent of the interest rates charged on other loans, so the realistic assumption is that the bank faces demand functions for loans which are imperfect substitutes. Little is known about systematic differences observed in actual interest rates charged by banks in each product class and maturity or on the contribution of product class and maturity to total interest rate dispersion in loans.

The former arguments can be extended to deposits. Here, products differ in terms of liquidity and payment facilities. Current Accounts and Saving Accounts are both highly liquid deposits but the former offers checking facilities while the latter does not. Bank Deposits satisfy the demand for savings, but since maturity can differ they can also be classified by liquidity. Liquidity/payment needs and saving needs seem very different and low consumer substitution should be expected among products that satisfy each need. But again, little is known about how substitution among deposit products and liquidity translates into systematic interest rate differences.

Individual banks can face different competitive market conditions. For instance, their respective local markets may have more or less competitors, have different operating costs and/or credit risk in each product class (loans) or can differ in terms of competitive strategy, low cost or high consumer services. All these are potential sources of ex post observed interest rate differences across banks. Interest rate dispersion can respond to bank heterogeneity which affects loan and deposit products offered by the same bank. One of the concerns in our analysis is to evaluate the contribution of bank fixed effects to the total variance observed in interest rates in different moments of time. It is an open question whether increasing competition, as markets get larger and the number of competitors increase, reduces or increases interest rate differences attributed to bank effects. To lower competitive pressures banks can shift towards a differentiation strategy that reduces the own price elasticity of demand and creates price differences in the market [Boot and Thakor(2000)]. Second, since banks differ in observed characteristics such as form of ownership (Commercial versus Savings banks), and geographic scope (National versus Regional/Local banks), we can ask for possible systematic differences in interest rates due to these observed characteristics.

Retail banking markets are for the most part local markets as services are provided at the bank's branches. Geographical markets can differ in terms of demand and supply conditions that create interest rate differences across them. Within a geographical market, homogeneous products can sell at different prices because consumers face search costs 
which create information differentiation [Stigler (1961)]. Banking products can be affected by information differentiation that creates interest rate dispersion [Martin et al. (2005)]. We cannot observe interest rates at the geographical (province) market level except in the cases where banks are local and have all their activities concentrated in one province. For the rest of banks, heterogeneity in market conditions will be part of the idiosyncratic factors included in the bank effects. However, we can still control for Province effects in the analysis of interest rate dispersion including in each province all banks that have business in it (with the assumption that a national bank sets the same interest rate in all markets). Geographic market structure variables, such as supply concentration, have been considered the main source of interest rate differences in retail banking under the traditional structure-conduct-performance paradigm, Berger and Hannan (1989), Hannan and Liang (1993). This approach continues dominating most recent work on market power of banks, including that of the papers referenced in the introduction about market power of European banks, but much less research exists on other sources of price differentiation in banking, such as product or bank effects, that we explore in this paper.

The official interest rate set by Banco de España (and from 1999 onwards by the Euro-system) and the interbank money market interest rate around it, sets a reference for bank interest rates in retail markets. Since individual banks are price takers in that market, they face a perfectly elastic demand of funds for the money received as deposits, and a perfectly elastic supply of funds for their loans. The interbank interest rate separates deposit from loan markets and interest rates are set in each market independently of the other. ${ }^{8}$ The equilibrium interest rate of loans and deposits will be a function of the interbank interest rate, common to all banks but changing over time. Of course, money market conditions are not the only macroeconomic conditions that can affect interest rates in retail banking. Inflation, business cycle, and economic specialization, are also relevant factors to consider which, among other things, can affect credit and the ex ante risk premium charged by banks in their loan products. Our analysis of interest rate differences will isolate time effects common to all banks.

\subsection{Methodology}

The main purpose of this section is to evaluate systematic interest rate differences across Product class, Maturity, Liquidity, Bank, Province and Time, over the 1989-2003 time period. We also want to evaluate the contribution of each source of potential differentiation to the total variance observed in interest rates. The framework of analysis is static in the sense that short-term deviations of interest rates from their long-term levels due to temporary shocks are ignored. They will be the main focus of the next section.

The evaluation will be made combining regression and analysis of variance. Our data allows us to compute interest rate differences for each product and each peer of banks every quarter, but to work with all bilateral differences is unpractical. One possibility is to evaluate the differences relative to the average of interest rates across all banks for each product. The other is to choose a particular market as a benchmark and explain interest rates spreads with the comparison market. The second alternative is more attractive, especially if the benchmark chosen is considered a highly competitive market. Then, differences in prices with respect to the benchmark can be easily translated into welfare losses. In this paper, the benchmark market and the reference interest rate are the interbank market and the one-day

8. This result is based on the Monti-Klein model of the banking firm, as surveyed in Freixas and Rochet (1997). 
interbank interest rate respectively. When computing differences with respect to the interbank interest rate, we remove from the interest rates of individual banks and products the common time effects introduced by the evolution of monetary conditions over time.

Interest rate differences can be evaluated in absolute or in relative terms. In our empirical analysis all interest rates are expressed in logs, and, thus, the difference with respect to the benchmark is in percentage or relative terms. The basic models to be estimated for loan and deposit products are formulated as follows

$$
\begin{array}{ll}
\ln r_{\mathrm{ijmt}}-\ln \mathrm{r}_{\mathrm{t}}=\mathrm{a}+\mathrm{a}_{\mathrm{i}}+\mathrm{a}_{\mathrm{j}}+\mathrm{a}_{\mathrm{m}}+\mathrm{a}_{\mathrm{t}}+\varepsilon_{\mathrm{ijmt}} & \text { if } i \text { is a loan } \\
\ln \mathrm{r}_{\mathrm{t}}-\ln \mathrm{r}_{\mathrm{ijmt}}=\mathrm{a}+\mathrm{a}_{\mathrm{i}}+\mathrm{a}_{\mathrm{j}}+\mathrm{a}_{\mathrm{m}}+\mathrm{a}_{\mathrm{t}}+\varepsilon_{\mathrm{ijmt}} & \text { if } i \text { is a deposit }
\end{array}
$$

where subscripts $i, j, m$ and $t$ refer to product $i$, bank $j$, geographical market $m$ and quarter $t$, respectively, while $r_{i j m t}$ is the product interest rate, $r_{t}$ is the one-day interbank interest rate and $a_{i}, a_{j}, a_{m}, a_{t}$ are Product, Bank, Market and Time dummy variables, respectively. The term $\varepsilon_{j i m t}$ is a random disturbance. In loans we have 15 different products, taking into account product classes and maturity, while in deposits the number of products is 10 . There are 50 provinces, 200 banks and 58 quarters.

\subsection{Dispersion of interest rate differentials. Stability over time and systematic differences across products, maturity, liquidity and type of banks}

Table 3 presents evidence on the explanation of interest rate differentials obtained from the estimation of model (1) for loan products. Column 1 shows the contribution to explained variance and differences in interest differentials across time periods for the pool of data. The 15 loan products are introduced into the model with a Product dummy variable for each of them. The other three columns of Table 3 , in addition to contribution to explained variance they also show estimated coefficients of explanatory variables in model (1). Each column corresponds to results from the estimation of model (1) in one of the three time periods in which the pool of data is divided. The 15 loan products are now grouped in 5 Product Classes and 3 Maturity (see Table 3). To avoid perfect collineality among the explanatory dummy variables, loans with Variable interest rate of less than one month maturity in Madrid by a large bank have been excluded from the explanatory variables of the regression. Therefore, the estimated coefficients of the variables in the upper part of the table indicate relative interest rate differentials with respect to the differential of loans with Variable interest rates with less than one month maturity (the omitted variable).

Time, Product, Bank and Market fixed effects explain almost two thirds of the variance in interest rate differentials in the whole 14 years period, $\mathrm{R}^{2}$ of $65.89 \%$. Among them, the main factor explaining interest rate differentials is Time, even though part of the time effect is already captured by the fact that the dependent variable is the relative difference with respect to the interbank rate. The empirical evidence indicates that in bank loan products there are time varying effects common to all banks, additional to those related to the evolution of the monetary policy, that explain the variation of interest rates charged by banks, for example the business cycle or changes in competitive conditions. Product and Bank time invariant specific effects have a similar contribution to explain the variance of differentials in loans, while Market (province) has a very minor effect. The first column of Table 3 also shows that interest rate differentials in loans increase over time: they are $15.4 \%$ higher, on average, in the five years period of 1994-1998 than in the four-years period 1989-1993, and the difference goes up to 33.6\% when we compare 1999-2003 with 1989-1993. 
The contribution of Bank, Product, Time and Market effects to explained variance of the interest rate differentials may change over time. The null hypothesis of structural stability of model (1) is explicitly tested and rejected with p values close to zero ${ }^{9}$. Consequently model (1) is estimated separately for each of the three time periods. Explained variation, $R^{2}$, is slightly increasing over time, from $53.28 \%$ in $1989-1993$ to $60.94 \%$ in $1999-2003$. Moreover, the null hypothesis of equal coefficients across Product classes and across Maturity and the null hypothesis of no partial contribution to explained variance is also rejected in all cases with the exception of Province, what shows no statistical significance in any of the periods.

In Table 3, all estimated coefficients for Product class are positive, meaning that in all of them relative differences are higher in average than in loans at Variable interest rate with maturity of less than a month. The coefficient of the intercept increases from 0.196 in the first time period to 0.322 in the last one, meaning that interest rate differential of loans at Variable interest rate of less than one month maturity, increases over time from 19.6\% in 1989-1993 to $32.2 \%$ in $1999-2003^{10}$. Coefficients of Receivables and Mortgages show no clear trend over time, while estimated coefficients of Credit Line and Personal loans increase every time period with respect to the period before. For example, Table 3 indicates that the interest rate differential of Mortgages is $5.0 \%$ higher than the interest rate differential of very low maturity loans at Variable interest rates in the period 1989-1993, and $10.8 \%$ higher during the rest of the period. On the other hand, Personal loans have a differential $12.2 \%$ higher in the first four years period and a differential $37.7 \%$ higher in the last one.

Relative differences in interest rates with respect to the interbank interest rate also vary systematically with loan maturity. Controlling for Product classes, the highest average differences appear in intermediate maturity, 3 months to 3 years. The pattern of the average differences is very similar in the second and the third period, which indicates that term structure of interest rates in loans has been quite stable since 1994.

Commercial and Savings banks start practically even in terms of relative differences of their respective interest rates with respect to the interbank interest rate, but at the end of the period the latter have $9.3 \%$ higher relative differences, on average, than the former. Differences between National and the rest of banks remain non-economically significant around values of $1.3 \%$. The geographical expansion and increase in market share of Savings banks during the period 1989 to 2003 coincides with a trend of higher relative interest rates in loan products than Commercial banks ${ }^{11}$. One explanation of this apparently contradicting evidence is that, in their expansion, Savings banks enter market segments of riskier borrowers and have to charge higher interest rates than established Commercial banks. But it could also be the case that in loans price is not the most determinant factor of market share and Savings banks provide other differentiated services such as accessibility (i.e. higher number of branches) than Commercial banks.

Time contributes to explained variance of interest rate differential in $29.25 \%$ in the first time period, in $11.99 \%$ during the second and in $22.31 \%$ in the third. Recall that this

\footnotetext{
9 The respective $\mathrm{F}$ statistics from the Chow tests of model stability are as follows. For loans: Periods 1 and 2, F(301, 1106747 $)=621.9$, Periods 1 and 3, $F(304,932970)=834.8$, Periods 2 and 3, $F(253,960163)=243.19$. For deposits: Period 1 and 2, F(296, 722361)=177.74, Periods 1 and $3 F(297,669275)=294.85$; Periods 2 and 3, F(247, 669238)= 284.6.

${ }^{10}$ The exact percentage difference is $\mathrm{e}^{0.322}-1=38 \%$ but to simplify the exposition we approximate the relative difference by the estimated coefficient shown in the table. The approximation error decreases as the value of the coefficient is lower.

11 The deposit (credit) share of savings banks raised from 42.4\% (35.3\%) in 1989 to $52.1 \%$ (46\%) in 2003.
} 
contribution is after taking away from the trend in interest rate the evolution of the interbank rate. The sharpest decline in the interbank rate occurs during the years 1994-1998 of nominal convergence before joining the Euro zone, precisely the period when Time shows the lowest contribution to explained variance. After 1998 the Time contribution to explained variance increases again and, thus, the introduction of the Euro only marginally reduced the effect of macroeconomic conditions on interest rate formation compared with the effect in the pre Euro period of 1989-1993.

Product class and Banks increase their respective partial contribution to explained variance from $18 \%$ in the period $1989-1993$ to around $22 \%$ the rest of the time the former, and from $28 \%$ to $41 \%$ the latter. Maturity decreases its partial contribution to explained variance over time being of just $0.8 \%$ in the last period. Overall, the pattern of contributions to explained variance by all the sources of differentiation considered remains stable since 1994 . It looks as if the pattern of differences in loan interest rates was already set in the period of nominal convergence and the Euro has consolidated that with little changes. The emerging pattern has as one of its distinct features the high contribution to explained variance of the variable Banks. In a period of decreasing and finally historically low interest rates banks may have had incentives to differentiate their offer of products in order to increase customer loyalty and reduce effective competition.

Table 4 presents the result of estimating model (1) for deposit products. The information is displayed in a similar way than Table 3. Now the omitted explanatory variable to avoid perfect collineality is Deposits of high liquidity in Madrid for a large bank and the results have to be interpreted as differentials with respect to the differential in this particular deposit product. In the entire time period between 1989 to 2003 Time, Product, Bank and Market fixed effects explain almost $70 \%$ of the variance in interest rate differentials. Product is by far the main factor contributing to the explanation of the variability in interest rate differentials; $86.84 \%$ of the explained variance has to be attributed to the variable Product, $7.37 \%$ to Bank and $4.3 \%$ to Time. The pattern of contributions to explained variance remains practically the same in the three periods. In bank deposits, all time variability in interest rates is explained by the evolution of the interbank rate, and other macroeconomic factors different from monetary conditions affect much less deposits' than loans' interest rate. The high contribution of Product to explain the variance indicates that deposit products are highly imperfect substitutes, probably because some of them satisfy liquidity demands and others saving demands. The relatively low explanatory power of Bank indicates that a bank does not succeed in differentiating its deposits from those of competing banks.

To interpret the results of the upper part of Table 4 we have to keep in mind that higher coefficients of the explanatory variables imply relatively lower interest rates on deposits received by the customers of the bank. The intercept, which is the estimated interest differential for the deposit product excluded from the regression, increases from 0.008 in the first time period to 0.237 in the last, but the main increase already takes place during 1994-1998 (0.221). Positive (negative) estimated coefficients indicate higher (lower) differential than that of the excluded product. Repo operations show a negative coefficient that increases in absolute value over time. For this product the interest rate differential was 0.012 (0.008+0.004), 1.2\%, in 1989-1993, and 0.041 (0.237-0.196) in 1999-2003. In Saving and in Current accounts the estimated coefficients increase over time, which together with the general increasing trend of the intercept imply higher differential over time. 
Differences in interest rates vary systematically with Liquidity. Surprisingly enough, Low liquidity, longer term deposits, pay lower interest rates than highly liquid deposits in the first time period (coefficients of Medium and Low liquidity of 0.097 and 0.144 , respectively). The results change over time and in 1999-2003 Low liquidity deposits have a differential 8.8\% lower than the differential of highly liquid deposits and, thus, the former pay higher interest rate than the later. The structure of interest rates on deposits has changed over time in an economically meaningful direction.

The persistent observed average differentials between Saving and Current accounts (the former pay lower interest than the latter) are more difficult to justify since both provide the same liquidity and the latter offers, in addition, checking facilities to the depositor. One possible explanation is that banks use Saving and Current accounts to better segment the market, offering the latter to more sophisticated consumers and the former to less sophisticated ones.

National banks pay marginally lower interest rates than local and regional banks in the period 1989-1993, around 2\%, but higher in 1999-2003. The pattern of average interest rate differentials by type of banks is fairly similar in deposits than it was in loans, with Saving banks being able to pay lower interest in deposits than Commercial banks, while increasing their market share in the deposit market over time. 


\section{Dynamic analysis}

The previous section has dealt with the absolute version of the Law of One Price. Interest rate differences are evaluated in this section under the relative version of the Law of One Price, which focuses on the speed at which transitory deviations from the across-banks long-term interest rate differentials are eliminated. In this dynamic framework we explain the interest rate gap (i.e. the difference in the interest rate of one bank product versus the corresponding benchmark) by the previous period interest rate gap, and dummy variables that are specific to the product and the bank. The inverse of the estimated coefficient on the lagged gap denotes the speed of convergence. If the speed of convergence increases over time it indicates that price differentials from external shocks will last a shorter period of time.

The methodology is based on estimating a partial adjustment model for each bank product controlling for bank specific effects and for common time varying external shocks. The partial adjustment model allows us to estimate not only the speed of convergence of each interest rate spread in response to external shocks, but also its long-term limit value. Therefore, we present evidence on across-bank long-term interest rate differentials and their evolution in the three time periods.

Speed of interest rate adjustment and long term interest rate differential are estimated using two different benchmarks, the one day interbank interest rate and the estimated marginal opportunity cost/revenue for each bank product. If products are homogeneous from the point of view of the buyer then differences in marginal costs across banks will not affect the selling price of the product which will be necessarily the same for all banks. When products are differentiated across banks and in general when banks have market power, differences in marginal costs translate in additional differences in price. Second, when the interest rate differential is computed with respect to marginal cost then the differential is the relative profit margin.

Comparing the results of speed of adjustment and long term interest rate differential with each benchmark we are in fact analyzing interest rate convergence on the one hand and relative profit margin convergence on the other. Additionally, if we conclude that the dynamics of interest rates is better explained by the dynamics of marginal costs than by the dynamics of the interbank rate, this would be evidence that banks have market power since bank prices vary with their respective marginal costs. Finally, some of the price differentials across products from Tables 3 and 4, differences between Mortgages and Personal loans or between Savings and Current accounts for example, can be due to differences in marginal costs across products and if these differences are eliminated then the remaining one will be close to the market power of banks in each product-market.

Marginal cost of loans includes a risk free interest rate of equal maturity than the respective loan product plus an estimated risk premium that accounts for the credit risk of the bank and product. The risk premium is estimated for each bank, loan product and year using data on defaults. For deposits, we substitute the one day interbank interest rate by the interest rate of a risk free investment opportunity for the bank of equal maturity than the respective deposit. 


\subsection{Speed of adjustment and long-term interest rate differential}

First, we test the hypothesis of convergence to the relative version of the Law of One Price taking as benchmark of the perfect competitive market price the one day interbank interest rate. Our concern is the speed of convergence in each time period and the long-term limit values. The model to be estimated is formulated as follows,

$y_{j t}=\delta+\alpha y_{j t-1}+\gamma_{1} D_{1} y_{j t-1}+\gamma_{2} D_{2} y_{j t-1}+$ TIME DUMMIES $+\eta_{j}+\varepsilon_{j t}$

where

$$
\begin{aligned}
& \eta_{\mathrm{j}} \sim \mathrm{iid}\left(0, \sigma_{\mathrm{j}}\right) \quad \varepsilon_{\mathrm{jt}} \sim \mathrm{iid}(0, \sigma) \\
& y_{j t}= \begin{cases}\ln r_{j t}-\ln r_{t} & \text { if the product is a loan } \\
\ln r_{t}-\ln r_{j t} & \text { if the product is a deposit }\end{cases}
\end{aligned}
$$

for each of the 25 bank products. Sub-index $j$ refers to the bank j quoting the product and sub-index $t$ refers to the time period. Explanatory variables are the one period lagged dependent variable, bank specific fixed effects, $\eta_{j}$, and time dummy variables. Bank specific effects control for differences in costs, policies, and ownership preferences of banks that can be treated as stable over time. Time dummies account for other external shocks common to all banks and products beyond those accounted for by the interbank rate. The formulation of the model allows for different values of the coefficient on the lagged dependent variable in each time period. To do so, the lagged dependent variable is multiplied by the dummy variables $D_{1}$ and $D_{2}$ that take value 1 if the observation belongs to period 1994-1998 or 1999-2003, and 0 otherwise, respectively.

The value of $\beta=\alpha-1$ is the Beta-convergence estimate of a product, that can be directly related, in absolute value, to the speed of convergence. A lower estimated $\alpha$ imply a faster Beta convergence, that is a higher speed in the process by which transitory shocks to interest rates get eliminated and interest differentials return to their long term values. The estimated value of the coefficient $\alpha$ provides the $\beta(\alpha-1)$ convergence value for the period 1989-1993. The $\beta$ convergence values of the other two five-year periods are given by $\left(\alpha+\gamma_{1}-1\right)$ and $\left(\alpha+\gamma_{2}-1\right)$, respectively. Negative (positive) $\gamma_{1}$ and/or $\gamma_{2}$ coefficients will indicate that convergence is faster (slower) in the respective five-year periods than in the first period (1989-1993). In other words, that interest rate adheres more (less) intensively to the relative version of the Law of One Price than in the first period.

Long-term relative interest rate differentials across banks for each product can be obtained by solving the equation of model (2) when dependent variables had reached their long-term value, $y_{t}=y_{t-1}$. Solving the model under this condition the long-term value of the interest rate differential is equal to $\delta /(1-\alpha)$. Since we allow for different intercepts across banks $\left(\delta+\eta_{i}\right)$ and time periods, and for changes in $\alpha$ in each time period, the long-term interest rate differentials will be computed using values of $\delta$ obtained averaging the estimated intercepts across banks and quarters for each product and each time period, and values of $\alpha$ corresponding to the respective time period.

Model (2) will be estimated in first differences with instrumental variables using Arellano and Bond (1988) panel data estimation technique, which chooses as instruments lags of the dependent variable uncorrelated with the error term. Table 5 reports the estimated 
values of $\alpha, \gamma_{1}$ and $\gamma_{2}$ for each of the 25 different products, which correspond to the test of the relative version of the Law of One Price. ${ }^{12}$

The null hypothesis of no beta-convergence $(\alpha=1)$ is rejected at a level of significance of $5 \%$ or less for all products. So, deviations from long term differentials due to external shocks seem to generate a process of convergence back to long term values. Estimated coefficients of the cross effect variables, $\gamma_{1}$ and $\gamma_{2}$, are some times non-significant, sometimes positive and sometimes negative (Table 5), so that no clear conclusion is reached on whether the adherence to the relative version of the law of One Price has increased over time. We also observe that the statistics from the test of second-order autocorrelation are relatively high for many loan products (i.e. we reject the hypothesis of non-autocorrelation at $1 \%$ in many cases). This means that there exists some idiosyncratic component within each bank in the motion of interest rate differentials that is not properly accounted for in the model specification. In the next section we show that this idiosyncratic component has to do with the credit risk premium of each bank and loan product that is not totally controlled by the bank specific effect (market power).

Estimated coeffcients of model (2) shown in Table 5 are summarized in Table 6 in the form of weighted averages (using as weights the relative number of observations of each product) for selected groupings of bank products: loans and deposits, maturity of loans, liquidity of deposits and product class. Lower values of the estimated parameter $\alpha$ shown in the table imply faster long term convergence. If the value of the parameter increases over time, the speed of convergence is reduced. The speed of convergence is often evaluated in terms of the half-life of price shocks, that is an estimation of the time required for a unit shock to dissipate by one half, $-\ln 2 / \ln \alpha$.

Over the 1989-1993 period, the average value of the parameter of the lagged dependent variable $\alpha$, for the 25 products, is 0.533 . This value implies a half-life of interest rate shocks of 1.1 quarters or 0.275 years. The speed increases up to a half-life interest shock of 0.244 years in the period 1994-1998, but it decreases slightly again in the last period. ${ }^{13}$ The speed of convergence is higher in loans than in deposits in the first time period, but the situation changes over time. In the 1999-2003 period, the adjustment parameter $\alpha$ goes up to 0.597 and the half-life of price shocks is 0.336 years compared to 0.258 in 1989-2003. For deposits, the speed of adjustment increases over time and in the 1999-2003 period the half-life of price shocks is 0.258, lower than 0.303 in 1989-1993. Long term loans, especially Mortgages, show lower speed of adjustment than short term loans. The speed of adjustment is higher for low liquidity than for high liquidity deposits. Among product classes, the slowest convergence occurs in Mortgages and Current Accounts, and the fastest in Credit Line and Repo type deposits. Estimated coefficients on the cross effect variables, $\gamma_{1}$ and $\gamma_{2}$, are sometimes non-significant, sometimes positive and sometimes negative (Table 6). In comparison with the speed of convergence over 1989-1993, ten years later the speed of convergence has increased for three of the four deposit products and has decreased for all loan products. Therefore, interest rates for deposits increase the adherence to the relative version of the Law of One Price and the interest rates of loans decrease its adherence.

12. Alternative estimations with pooled data for loans, deposits, loans (deposits) of given maturity (liquidity) were disregarded because all tests of equal model coefficients across pooled products rejected the null hypothesis at high levels of statistical significance. Besides, second order autocorrelation increased compared with that shown in Table 5. 13. Goldberg and Verboven (2004) obtain half-life values of 0.7 for car prices in Europe. 
In Table 6 we also show the implicit average long term differentials ${ }^{14}$, for the whole time period and for each of the three time periods. For the average of all 25 products, long interest rate differentials go from 0.408 in 1989-1993 to 0.789 in 1999-2003. This evolution is explained by the fact that interest rate differentials for loans increase from 0.394 to 1.121 , while they decrease less for deposits, from 0.428 to 0.324. Personal loans and Credit Line are the loan products with higher relative differentials in interest rates, both in 1989-1993 and in 1999-2003. Among deposit products, the highest differentials occur in Savings and Current Accounts. Overall, the results from Table 6 are consistent with the descriptive information in Table 3, which reported an increase over time in relative interest rate differentials for loan products and a minor reduction in interest rate differential for deposits.

\subsection{Explaining differences in interest rate differentials: Convergence in mark-ups}

The second part of the dynamic analysis will focus on explaining the evolution of interest rate differentials by looking at what part of that evolution can be attributed to changes in the opportunity cost of loans and to the marginal revenue of deposits. We assume that loan and deposit markets are separated and banks maximize profits in each of them. In the loan market, profits are equal to revenue from the interest rate charged in loans, less the opportunity cost of lending the funds, which is equal to the credit risk adjusted interest rate of a secured investment of same maturity than the loan. For deposits, profit is given by the risk free investments of equal maturity, minus the interest rate paid to the deposits. Each bank faces an inelastic demand for each loan product and an inelastic supply of each deposit product.

Bank products are matched with other investment opportunities and costs as follows. Loans and deposits with maturity until three months are matched with the one-day interbank rate. Loans and deposits from 3 months to 1 year with the 3 to 6 month interbank interest rate. Loans and deposits between 1 to 3 years with the 12 month interbank interest rate. Loans and deposits with maturity above three years with interest rates on 3-year government bonds. Finally, Mortgages are matched with the one-year Euribor interest rate since most of the mortgages are at variable interest rates indexed to the one year Euribor rate.

Given the risk free interest rate of a given maturity $i$, the opportunity cost of the loan is the interest rate $i$, that solves the equation,

$$
\left(1+i_{l}\right)(1-P D)+P D(1-L G D)\left(1+i_{l}\right)=1+i
$$

where $P D$ is the probability that the loan will default and $L G D$ is the loss given default, the amount of the loan that the bank will never recover. Solving the equation we obtain the opportunity cost for each bank and product,

$$
i_{l}=\frac{i+P D \cdot L G D}{1-P D \cdot L G D}
$$

14. Long term differentials are equal to $\frac{\delta}{1-\alpha}$, where $\delta$ and $\alpha$ come from the estimates reported in Table 5: the slope $\alpha$ is the one reported in the Table, while $\delta$ is obtained as the average of the residual $y_{j t}-\alpha y_{j t-1}-\gamma_{2} D_{1} y_{j t-1}-\gamma_{2} D_{2} y_{j t-1,}$, as intercept information is lost when taking first differences. 
For each of the five loan classes and for each individual bank and year, the PD is estimated from the Credit Register database as the proportion of bank loans in default at the end of the year in the respective product class. The LGD are taken from BCBS (2004) as follows: $25 \%$ for Mortgages and credit at Variable interest rate, $45 \%$ for Credit Line and Receivables and $85 \%$ for Personal loans. ${ }^{15}$ Figure 4 shows the evolution of the one-day interbank rate and the opportunity costs of the five loan product classes. To compute opportunity cost of loans we assign to loans made in period t the PD of period $t+1$. The evolution of the opportunity cost of loans, relative (i.e. divided by) to the interbank interest rate, reflects the business cycle of the Spanish economy, with higher probabilities of default in periods of low economic growth, such as the early nineties. Credit line and Personal have the highest ratio between opportunity costs and one day interbank rate, around 1.55 average for the whole period, with a moderate increase in the period 1994-1998 (1.65). In Receivables, Mortgage and Variable the average ratios are 1.25, 1.20 and 1.07, respectively. For Mortgages, the ratio goes from 1.05 in the period 1988-1993 to 1,32 in the period 1999-2003, due mainly to the increasing gap between the one day interbank and the five-year government bond rate.

Profit maximizing banks facing an inelastic demand (supply) of loans (deposits), with absolute value $\varepsilon_{l}\left(\varepsilon_{\mathrm{d}}\right)$, will set interest rates on loans (deposits) applying a mark up (mark down) $K_{l}=\varepsilon_{l} /(\varepsilon-1)\left(K_{2}=\varepsilon_{d} /\left(\varepsilon_{d}+1\right)\right)$ to the opportunity cost $i(i)$. Substituting the profit maximizing interest rate in the calculation of the relative interest rate differential we obtain,

$$
\begin{aligned}
& \ln y_{j t}=\ln K_{1}+\ln \frac{i+P D \cdot L G D}{r(1-P D \cdot L G D)} \quad \text { for loans } \\
& \ln y_{j t}=\ln K_{2}+\ln \frac{i}{r} \quad \text { for deposits }
\end{aligned}
$$

where $\ln y_{j t}$ is the relative interest rate differential computed as in model (2). Relative interest rate differentials used as dependent variable in model (2) are equal to the sum of the log of the mark up (mark down) and the log of the ratio between the opportunity cost of the loan (revenue from deposits) and the one-day interbank rate. As long as the relationship between the term structure of risk free interest rates remains stable over time, interest rate differentials in deposits will change in parallel with changes in the mark down $K_{2}$. For loans, the interest rate differential depends on the mark up, interest rates and default probabilities, $P D$. If the term structure of interest rates, the mark up and the $P D$ all remain stable over time, interest rate differentials of loans will still vary with $r$, the money market interest rate. In periods when $r$ is decreasing, interest rate differentials will increase even if the rest of terms remain stable over time.

One way to isolate the impact on the spreads of changes in the term structure of interest rates and credit risk, is to estimate the speed of convergence and long term equilibrium values for the log of mark up (mark down). To do so, we substitute the values of the interest rate differentials determined by (3) in model (2). After some arrangements of the terms of the equation, model (2) is modified so that the interest rate differential is now computed with respect to $\ln i_{i}$ instead of $\ln r_{t}$. The speed and convergence values of the

15. That is, we use supervisors' best estimates of LGD as lay out in the Foundation-IRB approach Basel II proposals. 
mark up are interesting by themselves because they are directly related to the degree of market integration and the market power of banks, respectively.

Estimated slope coefficients for this variation on model (2), for each of the 25 products, are presented in Table 7. Convergence in mark ups is rejected in six cases (i.e. $\alpha$ is statistically equal to 1). This happens mostly in the first time period and always in loan products. In Personal loans with maturity over 3 years, the null hypothesis of $\alpha=1$ is not rejected in any of the periods. Second, the speed of convergence starts very low in the 1989-1993 period, with relatively high values of the slope coefficient, particularly for loan products, but it increases over time since estimated coefficients for the cross variables $\left(\gamma_{1}\right.$ and $\left.\gamma_{2}\right)$ are negative and in many cases statistically significant. In addition second order autocorrelation is rejected in all products and confirms the consistence of the parameter estimates when convergence is evaluated relative to opportunity costs or revenues.

The summary of results in Table 8 makes clearer that in the 1989-1993 period the mark up adjusted slower to its long term value in loans than in deposits, with slope coefficients of 0.773 and 0.554 , respectively, and a smaller difference remains ten years later, 0.569 (0.773-0.214) and 0.467 (0.554-0.087). The unambiguous negative estimated values of the $\gamma$ coefficients provide evidence in favor of an increase of the speed of adjustment in interest rates over time. However, most of this increase occurs already in the years 1994-1998, the years of nominal convergence of the Spanish economy in preparation for joining the Euro zone. There is no empirical support for a stronger relative version of the Law of One Price since 1999, when Spain became a formal member of the Euro zone, with the exception of Mortgages, for which the speed of adjustment only increases after 1999.

The comparison of Tables 7 and 8 reveals that the speed of adjustment in the differential of loan interest rates with respect to the interbank rate is higher than the speed with respect to the opportunity cost, although the former remains quite similar in 1999-2003 to that of the 1989-1993 period. The pattern of results is more similar for the deposit products. Banks seem to smooth the adjustments in interest rates of loans to changes in the credit risk conditions and slow the overall speed of adjustment, compared with the adjustment to changes in the monetary conditions. From Table 8 we can say that the increase in speed of adjustment for loans, negative $\gamma$, after 1994 obeys to faster reaction under changes in credit risk conditions in loan markets; in other words, to possible changes in the credit policies of banks.

The speed of adjustment is higher (lower estimated $\alpha$ ) for Mortgages than for loans of other maturity, specially in the first and the third time periods. In all other cases, speed of adjustment decreases as loan maturity increases (the main difference appears to be between maturity of more and less than one year). ${ }^{16}$ Since the interest rates are marginal rates, the pattern of speed of adjustment across loans of different maturity probably reflects the smoothing practice of banks in the transmission of interest rates of loans to changes in costs, consistent with the practice of relational lending, Berger and Udell (1992).

Long-term equilibrium mark ups (in logs) of loans, Table 8, are much lower (by a factor of 3) than interest rate differentials shown in Table 6 . The increase over time in relative

16. We have performed tests of equal weighted averages of speed of adjustment for loans and for deposits products and for loans of low and high maturity. The $z$ statistic of the test is computed taking into account the variance covariance matrix of all the estimated coefficients weighted in the comparison. In both cases the null hypothesis of no difference was rejected ( $z=-2.59$ and $z=7.51$, respectively). 
spreads with respect to interbank rate, Table 6, are due in an important part to the fact that the credit risk premium over the risk free interest rate does not decrease at the same path as the risk free interest rate. Banks' interest rates in loans respond to marginal costs of the bank and this creates dispersion in interest rates and in differentials with respect to the one day interbank rate, violating the absolute version of the Law of One Price.

In loans of more than 3 years, excluded Mortgages, in loans between 1 and 3 months and in Credit lines, the long term mark up is below 1 (negative log of mark up) during the four-year period 1989-1993 (and in two cases also in 1994-1998). These are years of high credit risk and high rate of defaults in bank loans (Figure 4) that apparently banks' credit policies did not anticipated at the time the loan was granted. In recent years all loan products have a positive contribution to gross profits. The equilibrium mark up in loans is higher in the third time period, 1999-2003, than in the first one, 1989-1993, evidence that suggests an increase in market power of banks in loan products over time. ${ }^{17}$

On average, the mark down in deposits is similar in the first and the last periods, around 0.40. During the 1994-1998 period the mark down is lower, implying less market power and presumably higher competition. Current Accounts, and specially Saving Accounts, are the deposit products with higher mark down, suggesting they have the less competitive markets. ${ }^{18}$

17. The long-term values shown in the final columns of the table are long term mark ups in logs. The actual mark up is obtained taking the anti-log value of the long-term estimated coefficient. For example in the period 1999-2003 the mark up in loans is in average 1.26 [exp (0.234)]. This implies an absolute elasticity of demand of almost $5\left[\left(\varepsilon_{1} /\left(\varepsilon_{1}-1\right)=1.26\right]\right.$. Since in the profit-maximizing price the Lerner index is equal to the inverse of the elasticity of demand, the index is $20 \%$. 18. The actual mark down applied to the risk free interest rate that determines the marginal revenue the bank obtains from deposits is the inverse of the anti log of the long term value shown in Table 9. For the 0.4 value, the mark down is 0.67 [exp(-0.40)]. This implies an elasticity of supply of deposits of 2 and a Lerner index of $50 \%$. 


\section{Conclusion}

Interest rate differentiation is a persistent phenomenon in Spanish retail banking, a situation that has not changed substantially with the introduction of the Euro. Differences in interest rates persist across banks and between product classes in both loans and deposits. The evidence found in the paper casts some doubts on whether Spanish retail banking can be considered a single market from the point of view of the absolute version of the Law of One Price, a conclusion that should moderate the expectations about future European banking integration. Dispersion is higher in loans than in deposits, especially due to bank specific effects that reflect heterogeneity in banks' credit policies. Among these policies, relational lending can be the reason why the relative version of the Law of One Price finds stronger support as loan maturity decreases.

The test of the relative version of the Law of One Price provides evidence about the speed of adjustment of interest rates differentials with respect to interbank rate. It also shows that, in the case of loans, the dynamics of interest rates are not well captured by the dynamics of the interbank rate as the hypothesis of perfect competition would predict (the estimated empirical model shows clear evidences of second order autocorrelation). In addition, the speed of adjustment does not change in any clear pattern over time. When the dynamics of interest rates are modeled by the dynamics of the mark up over marginal cost, then the second order autocorrelation disappears and the parameter that measures the speed of adjustment changes over time in a way consistent with higher speed of adjustment, higher adherence to the Law of One Price. However if interest rates of individual banks respond to marginal costs of the bank, the market power of the bank, implicit in this result, goes against the absolute version of the Law of One Price, since this will be an additional source of price differentiation.

Another relevant result of the paper is that conventional measures of market power such as relative profit margins or the Lerner index increase over time in all loan products and remain stable in deposits with the exception of Repo type deposits, for which it decreases. Other than by the decline in interest rates and absolute profit margins during the period of study, the evidence does not support that market power of Spanish banks has decreased in a significant way. This conclusion is reached even when margins are computed over credit risk adjusted opportunity costs of loans. Same caveats are however in order.

First, increasing mark ups in loans may just reflect the fact that the marginal operating cost of lending is not declining at the same pace as the interbank interest rate during the period. Higher relative gross margins in loans are needed to compensate for the trend in marginal operating costs. Data does not allow to compute separate marginal operating costs for each loan or deposit product. Second, consumers of banking services have benefited from important improvements in quality of services during the period of study, which have to be accounted for to evaluate their welfare. Third, and specially important, increasing competition and loose monetary policies have forced banks to improve credit risk management and to eliminate cross subsidization of products. There is evidence that in the 1989-1993 period, with high money market interest rates, banks had very high profit margins in deposits that compensated for negative profit margins (after credit risk) in personal and business loans. When money market interest rates went down and competition increased within a full liberalization of the retail banking markets, subsidization became no 
longer possible and banks adjusted the interest on bank products to their respective marginal cost (loans) or marginal revenues (deposits). Products such as Personal and Credit line loans and Current and Saving Accounts appear as markets where banks are able to currently maintain higher economic margins, but in other products such as Mortgages or Deposits the margins are relatively low and non increasing over time. Business credit and liquid deposits are the markets where banking competition is expected to be more intense in the near future. 


\section{REFERENCES}

ANGELINI, P., and N. CETORELLI (2003). "The effects of regulatory reforms on competition in the banking industry", Journal of Money Credit and Banking, 35, pp. 663-684.

ARELLANO, M., and S. BOND (1988): Dynamic panel data estimation using DPD-A guide for users, Working Paper, 88/15, The Institute for Fiscal Studies.

ASPLUND, M., and R. FRIBERG (2001). "Deviations from the law of one price in Scandinavian duty-free stores", American Economic Review, 91, pp. 1072-1083

BAELE, L., A. FERRANDO, P. HÖRDAHL, Y. KRYLOVA and C. MONNET (2004). "Measuring European financial integration", Oxford Review of Economic Policy, Vol. 20 n. ${ }^{\circ}$. 4, pp. 509-530.

BASEL COMMITTEE ON BANKING SUPERVISION (2004). International convergence of capital measurement and capital standards, June.

BERGER, A., and T. HANNAN (1989). "The price-concentration relationship in banking", Review of Economics and Statistics, 71, pp. 291-299.

BERGER, A., and G. F. UDELL (1992). "Some evidence on the empirical significance of credit rationing", Journal of Political Economy, 100, pp. 1047-1077.

BIKKER, J., and K. HAAF (2002). "Competition, concentration and their relationship: An empirical analysis of the banking industry," Journal of Banking and Finance, Vol. 26(11), pp. 2191-2214.

BOOT, A., and A. THAKOR (2000). "Can relationship banking survive competition”, Journal of Finance, 55, pp. 679-713.

CECCHETTI, S., M. NELSON and R. SONORA (2002). "Price level convergence among United States Cities: Lessons for the European Central Bank", International Economic Review, 43, pp. 1081-1099.

COURVOISIER, S., and R. GROPP (2002). "Bank concentration and retail interest rates", Journal of Banking and Finance, 26, pp. 2155-2189.

ENGEL, C., and J. ROGERS (2001). "Violating the Law of One Price: Should we make a Federal case out of it?", Journal of Money Credit and Banking, 33, pp. 1-15.

FERNANDEZ DE GUEVARA, J., and J. MAUDOS (2004). Explanatory factors of the market power in the Spanish banking system, Mimeo, University of Valencia.

FRANKEL, J., A. ROSE (1996) "A panel of Purchasing Power Parity: Mean reversion within and between countries", Journal of International Economics, 40, pp. 209-224.

FREIXAS, X., and J. C. ROCHET (1997). Microeconomics of Banking, The MIT Press.

GODDARD, J., P. MOLYNEUX and J. WILSON (2004). "Dynamics of growth and profitability in banking", Journal of Money, Credit and Banking, 36, pp. 1069-1090.

GOLDBERG, P. K., and F. VERBOVEN (2001). "The evolution of price dispersion in the European car market", Review of Economic Studies, pp. 811-848.

- (2004). "Cross-country price dispersion in the euro area: a case study of the European car market", Economic Policy, October, pp. 483-521.

HANNAN, T., and N. LIANG (1993). "Inferring market power from time-series data. The case of the banking firm", International Journal of Industrial Organization, Vol. 11, issue 2, pp, 205-218.

JIMÉNEZ, G., V. SALAS and J. SAURINA (2004). Determinants of collateral, Working Paper n. ${ }^{\circ}$ 0420, Banco de España.

JIMÉNEZ, G., SAURINA, J., (2004). "Collateral, type of lender and relationship banking as determinants of credit risk", Journal of Banking and Finance, 28, pp. 2191-2212.

MARTIN, A., V. SALAS and J. SAURINA (2005). Interest rate dispersion in deposit and loan markets, Working Paper n. ${ }^{\circ} 0506$, Banco de España.

MAUDOS, J. and J. FERNÁNDEZ GUEVARA (2004). "Factors explaining the interest margin in the banking sectors of the European Union", Journal of Banking and Finance, 28/9, pp. 2259-2281.

SALAS, V., and J. SAURINA (2003): "Deregulation, market power and risk behavior in Spanish banks", European Economic Review, 47, pp. 1061-1075.

STIGLER, G. (1961). "The economics of information”, Journal of Political Economy, 69, pp. 213-225.

TAYLOR, A. (2002). "A century of Purchasing Power Parity", Review of Economics and Statistics, 84, pp. 139-150. 
Table 1. Banking products by maturity and liquidity.

Note: There are some cells to which we have assigned more than one single product. On the loan side, Loans at variable interest

rate of less than 1 month and from 1 to 3 months are grouped under the maturity label of " $<3 \mathrm{~m}$ ". On the deposit side, Deposit from 3 to 6 months, 6 months to 1 year, 1 year to 2 years and Repo operations from 3 months to 6 months and 6 months to 1 year are grouped under the "Medium" liquidity label. 
Table 2. Interest rate dispersion for all bank products, for loans and for deposits. Summary statistics.

Interbank refers to the one-day interest in the interbank market. The Differential with the Interbank rate panel shows the average difference between the interest rate of the Loan/Deposit and the one-day interbank rate in percent points (Absolute) and the average of differences divided by the respective interest rate of Loan/Deposit (Relative). Dispersion includes 90th - 10th, the average difference between the interest of the 90th and the 10th percentiles of the distribution of interest rates divided by the average interest rate of the product. Coefficient of Variation is the ratio between standard deviation and the mean of the distribution of interest rates across banks and products.

\begin{tabular}{|c|c|c|c|c|c|}
\hline & & $1989-2003$ & 1989-1993 & 1994-1998 & 1999-2003 \\
\hline Interbank (\%) & & 8.72 & 13.66 & 7.35 & 3.61 \\
\hline \multicolumn{6}{|c|}{ Differential with Interbank } \\
\hline \multirow[t]{2}{*}{ All products } & Absolute (p.p) & 2.74 & 3.47 & 2.46 & 1.92 \\
\hline & Relative (\%) & 45.42 & 41.38 & 38.57 & 61.72 \\
\hline \multirow[t]{2}{*}{ Loan products } & Absolute (p.p) & 3.02 & 2.98 & 3.26 & 2.76 \\
\hline & Relative (\%) & 27.04 & 16.98 & 29.60 & 40.17 \\
\hline \multirow[t]{2}{*}{ Deposit products } & Absolute (p.p) & 2.34 & 4.16 & 1.40 & 0.81 \\
\hline & Relative (\%) & 70.44 & 75.47 & 50.68 & 90.07 \\
\hline \multicolumn{6}{|c|}{ Dispersion measures } \\
\hline \multirow[t]{2}{*}{ All products } & $90^{\text {th }}-10^{\text {th }}(\%)$ & 42.01 & 34.56 & 40.90 & 55.71 \\
\hline & Coefficient of Variation (\%) & 17.40 & 13.82 & 17.12 & 23.63 \\
\hline \multirow[t]{2}{*}{ Loan products } & $90^{\text {th }}-10^{\text {th }}(\%)$ & 36.07 & 23.59 & 39.22 & 52.43 \\
\hline & Coefficient of Variation (\%) & 15.19 & 9.80 & 16.66 & 22.10 \\
\hline \multirow[t]{2}{*}{ Deposit products } & $90^{\text {th }}-10^{\text {th }}(\%)$ & 50.09 & 49.90 & 43.18 & 60.03 \\
\hline & Coefficient of Variation (\%) & 20.41 & 19.45 & 17.74 & 25.64 \\
\hline
\end{tabular}


Table 3. Determinants of interest rate differential and contribution to explained variance

of Time, Product Class, Maturity, Bank and Province in selected time periods. Loans.

The dependent variable is $\ln r_{\text {ijmt }}-\ln r_{t}$, where In $r_{\text {ijmt }}$ stands for the interest rate of Bank $j$ on Product $i$ at Time $t$ in province $m$. Ln $r_{\mathrm{t}}$ is the one-day interbank interest rate at Time $t$.

\begin{tabular}{|c|c|c|c|c|}
\hline & $1989-2003$ & 1989-1993 & 1994-1998 & 1999-2003 \\
\hline Intercept ${ }^{\mathrm{a}, \mathrm{b}}$ & & 0.196 & 0.265 & 0.322 \\
\hline \multicolumn{5}{|l|}{ Product Class $^{\mathrm{a}}$} \\
\hline Receivables & & 0.115 & 0.212 & 0.149 \\
\hline Credit Lines & & 0.042 & 0.129 & 0.206 \\
\hline Personal Loans & & 0.122 & 0.278 & 0.377 \\
\hline Mortgages & & 0.050 & 0.108 & 0.108 \\
\hline \multicolumn{5}{|l|}{ Maturity ${ }^{a}$} \\
\hline 1 to 3 Months & & $-0.002^{\star}$ & 0.036 & 0.039 \\
\hline 3 Months to 1 Year & & 0.036 & 0.085 & 0.076 \\
\hline 1 to 3 Years & & 0.084 & 0.112 & 0.085 \\
\hline More than 3 Years & & 0.028 & 0.033 & 0.026 \\
\hline \multicolumn{5}{|l|}{ Differences by type of entity } \\
\hline Saving Banks-Commercial Banks ${ }^{a}$ & & -0.005 & 0.078 & 0.093 \\
\hline Non National Banks - National Banks ${ }^{a}$ & & -0.013 & 0.016 & 0.011 \\
\hline $\mathbf{R}^{2}$ & $65.89 \%$ & $53.28 \%$ & $57.98 \%$ & $60.94 \%$ \\
\hline \multicolumn{5}{|l|}{ Contribution to explained variance ${ }^{a, c}$} \\
\hline Time & $42.73 \%$ & $29.25 \%$ & $11.99 \%$ & $22.31 \%$ \\
\hline Product & $20.22 \%$ & & & \\
\hline Product class & & $17.85 \%$ & $23.79 \%$ & $21.72 \%$ \\
\hline Maturity & & $8.94 \%$ & $3.15 \%$ & $0.79 \%$ \\
\hline Bank & $22.57 \%$ & $28.31 \%$ & $40.70 \%$ & $41.38 \%$ \\
\hline Province & $0.00 \%$ & $0.00 \% *$ & $0.00 \% *$ & $0.00 \% *$ \\
\hline \multicolumn{5}{|l|}{$\begin{array}{l}\text { Differences in average relative } \\
\text { differentials in time periods } \mathrm{s}^{\mathrm{a}}\end{array}$} \\
\hline Period 94-98 - Period 88-93 & 0.154 & & & \\
\hline Period 99-03 - Period 88-93 & 0.336 & & & \\
\hline Test Period 94-98=Period 99-03 (P-value) & 0.000 & & & \\
\hline Number of observations & 1.455 .798 & 495129 & 522220 & 438449 \\
\hline
\end{tabular}


Table 4. Determinants of interest rate differential and contribution to explained variance of Time, Product Class, Maturity, Bank and Province in selected time periods. Deposits.

The dependent variable is $\ln r_{\mathrm{t}}-\ln r_{\text {rimt }}$, where $\ln r_{\text {iimt }}$ stands for the interest rate of Bank $j$ on Product $i$ at Time $t$ in province $m$. Ln $r_{\mathrm{t}}$ is the one-day interbank interest rate at Time $t$.

\section{Intercept ${ }^{\mathrm{a}, \mathrm{b}}$} $1989-1993$ 1994-1998 1999-2003

Product Class ${ }^{\mathrm{a}}$

Saving accounts

Current accounts

Repo operations

Liquidity ${ }^{\mathrm{a}}$

Medium

Low

Differences by type of entity

Saving Banks-Commercial Banks

Non National Banks - National Banks ${ }^{\mathrm{a}}$

0.008

0.221

0.237

$\mathbf{R}^{2}$

Contribution to explained variance ${ }^{\mathrm{a}, \mathrm{c}}$

Time

Product

Product class

Liquidity

Bank

Province

Differences in average relative

differentials in time periods ${ }^{a}$

Period 94-98 - Period 88-93

1.040

0.867

0.325

0.004

0.867

0.377

1.369

$-0.149$

$-0.196$

Period 99-03 - Period 88-93

Test Period 94-98=Period 99-03 (P-value)

0.097

0.016

$0.003^{*}$

0.144

$-0.013$

$-0.088$

$\begin{array}{lll}0.093 & 0.068 & 0.098\end{array}$

$\begin{array}{lll}0.019 & -0.000^{*} & -0.080\end{array}$

\begin{tabular}{|c|c|c|}
\hline $63.57 \%$ & $66.28 \%$ & $69.32 \%$ \\
\hline
\end{tabular}

Number of observations

$4.31 \%$

$4.13 \%$

$0.75 \%$

$86.84 \%$

$6.12 \%$

$60.85 \%$

$67.52 \%$

$1.48 \%$

$7.37 \%$

$0.00 \%$ *

$7.96 \%$

$0.09 \%$

$63.36 \%$

$0.00 \%$ *

$9.03 \%$

$0.44 \%$

$9.28 \%$

$0.00 \% *$

anless specified with $\left(^{*}\right)$, all p-values from the F-tests for statistical lack of sign

for a large bank.

$-0.104$

$-0.051$

0.000

${ }^{\mathrm{C}}$ We show the ratio of partial sum of squares of each group with respect to the sum of squares of the model, which explains why they do not add up to 1. 
Dependent variable is $\ln r_{\mathrm{jit}}-\ln r_{\mathrm{t}}$ for loan products and $\ln \mathrm{r}_{\mathrm{t}}-\ln \mathrm{r}_{\mathrm{ijt}}$ for deposit products, where $\mathrm{r}_{\mathrm{ijt}}$ is the interest rate of Bank $j$ on Product $i$ at Time $t$ $r_{t}$ is the one-day interbank interest rate.

The estimated equation is $\mathrm{Y}_{\mathrm{jt}}=\delta+\alpha \mathrm{Y}_{\mathrm{jt}-1}+\gamma_{1} \mathrm{D}_{1} \mathrm{Y}_{\mathrm{jt}-1}+\gamma_{2} \mathrm{D}_{2} \mathrm{Y}_{\mathrm{jt}-1}+$ Year Dummies $+\eta_{\mathrm{j}}+\varepsilon_{\mathrm{ijt}}$

Coefficients reported have been obtained applying the Arellano \& Bond estimation technique for each product, using up to four lags of the dependent variable as instruments.

\begin{tabular}{|c|c|c|c|c|c|c|}
\hline & $\alpha$ & $\gamma_{1}$ & & $\gamma_{2}$ & & $\begin{array}{l}\text { P-values of } 2^{\text {ntu }} \text { order } \\
\text { autocorrelation statistic }\end{array}$ \\
\hline RECEIVABLEless3months & $0.559 * * \star$ & 0.062 & $\star \star$ & 0.085 & *** & 0.000 \\
\hline RECEIVABLE3months-1year & $0.568 * \star \star$ & 0.010 & & 0.049 & * & 0.000 \\
\hline RECEIVABLE1year-3years & $0.403 * * *$ & -0.147 & $\star \star \star ~$ & 0.016 & & 0.401 \\
\hline CREDITLINEless3months & $0.491 * \star *$ & -0.201 & $\star * *$ & -0.111 & ** & 0.085 \\
\hline CREDITLINE3months-1year & $0.433 * * *$ & -0.023 & & 0.019 & & 0.000 \\
\hline CREDITLINE1year-3years & $0.591 * \star *$ & 0.061 & 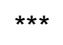 & 0.113 & *** & 0.000 \\
\hline CREDITLINEmore3years & $0.462 * * *$ & -0.071 & $\star \star$ & 0.027 & & 0.120 \\
\hline PERSONALless3months & $0.497 \star \star \star *$ & -0.038 & & 0.046 & & 0.342 \\
\hline PERSONAL3months-1year & $0.412 \star \star \star *$ & -0.042 & & 0.012 & & 0.105 \\
\hline PERSONAL1year-3years & $0.562 * * *$ & 0.027 & & 0.125 & $\star \star \star *$ & 0.000 \\
\hline PERSONALmore3years & $0.609 \star \star \star *$ & 0.023 & & 0.179 & 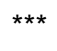 & 0.000 \\
\hline MORTGAGEmore3years & $0.593 * \star *$ & 0.074 & $\star \star \star *$ & 0.141 & $\star \star \star *$ & 0.000 \\
\hline VARIABLEless1month & $0.395 * \star \star$ & 0.043 & & 0.132 & & 0.121 \\
\hline VARIABLE1month-3months & $0.413 \star \star \star *$ & 0.000 & & 0.169 & ** & 0.007 \\
\hline VARIABLEmore3months & $0.514 * \star \star$ & 0.025 & & 0.245 & $* \star *$ & 0.000 \\
\hline DEPOSITSless3months & $0.616 \star \star \star *$ & -0.183 & $\star \star \star *$ & -0.135 & $\star *$ & 0.686 \\
\hline DEPOSITS3months-6months & $0.576 \star \star \star *$ & 0.050 & & 0.106 & ** & 0.808 \\
\hline DEPOSITS6months-1year & $0.507 * \star *$ & -0.004 & & 0.059 & & 0.097 \\
\hline DEPOSITS1year-2years & $0.594 * * *$ & -0.132 & $\star \star \star *$ & -0.125 & *** & 0.133 \\
\hline DEPOSITSmore2years & $0.709 * \star *$ & -0.073 & & -0.334 & $* \star *$ & 0.153 \\
\hline REPOless3months & $0.511 * \star *$ & -0.124 & * & -0.013 & & 0.624 \\
\hline REPO3months-6months & $0.482 * \star *$ & -0.077 & & 0.148 & ** & 0.180 \\
\hline REPO6months-1year & $0.484 * * *$ & -0.145 & $\star \star$ & -0.058 & & 0.687 \\
\hline CURRENT & $0.610 * * *$ & -0.044 & & -0.086 & & 0.821 \\
\hline SAVINGS & $0.562 * \star * *$ & -0.191 & $\star \star \star *$ & -0.152 & $\star * \star$ & 0.880 \\
\hline
\end{tabular}

The null hypothesis of $\alpha=1$ is rejected at p-values of $5 \%$ or less in all the products. 
Table 6. Summary of slope coefficients $\alpha$ and long term mark up.

\begin{tabular}{|c|c|c|c|c|c|c|c|c|}
\hline & & \multicolumn{3}{|c|}{ Speed of adjustment } & \multicolumn{4}{|c|}{ Long term mark up } \\
\hline & & $\alpha$ & $\gamma_{1}$ & $\gamma_{2}$ & $1989-2003^{\mathrm{a}}$ & $1989-1993^{a}$ & $1994-1998^{b}$ & $1999-2003^{b}$ \\
\hline Pooled regression & POOL & 0.533 & -0.041 & 0.028 & 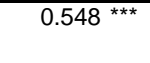 & $0.408^{\star \star \star \star}$ & $\begin{array}{c}0.529 \\
(0.000)\end{array}$ & $\begin{array}{c}0.789 \\
(0.000)\end{array}$ \\
\hline \multirow[t]{2}{*}{ By class } & Loans & 0.511 & -0.006 & 0.086 & 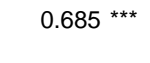 & $0.394 * \star \star$ & $\begin{array}{c}0.694 \\
(0.000)\end{array}$ & $\begin{array}{c}1.121 \\
(0.000)\end{array}$ \\
\hline & Deposits & 0.564 & -0.088 & -0.052 & 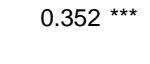 & $0.428 * \star \star$ & $\begin{array}{c}0.291 \\
(0.000)\end{array}$ & $\begin{array}{c}0.324 \\
(0.000)\end{array}$ \\
\hline \multirow[t]{6}{*}{ By maturity } & More than 3 years & 0.558 & -0.009 & 0.126 & $0.990 * * *$ & 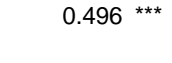 & $\begin{array}{c}0.890 \\
(0.000)\end{array}$ & $\begin{array}{c}1.838 \\
(0.000)\end{array}$ \\
\hline & 1 year -3 years & 0.531 & -0.005 & 0.092 & $0.934 * \star \star$ & $0.516 * \star \star *$ & $\begin{array}{c}0.998 \\
(0.000)\end{array}$ & $\begin{array}{c}1.518 \\
(0.000)\end{array}$ \\
\hline & 3 months-1year & 0.481 & -0.008 & 0.076 & $0.603 * \star *$ & $0.386 * \star *$ & $\begin{array}{c}0.622 \\
(0.000)\end{array}$ & $\begin{array}{c}0.915 \\
(0.000)\end{array}$ \\
\hline & 1month-3 months & 0.499 & -0.031 & 0.051 & $0.563 * * *$ & $0.371 * \star *$ & $\begin{array}{c}0.576 \\
(0.000)\end{array}$ & $\begin{array}{c}0.838 \\
(0.000)\end{array}$ \\
\hline & less than 1 month & 0.395 & 0.043 & 0.132 & $0.207 * \star *$ & $0.149 * \star \star$ & $\begin{array}{c}0.167 \\
(0.000)\end{array}$ & $\begin{array}{c}0.359 \\
(0.000)\end{array}$ \\
\hline & Very long term (Mortgages) & 0.593 & 0.074 & 0.141 & $0.533 * \star *$ & $0.110 * \star \star$ & $\begin{array}{c}0.543 \\
(0.000)\end{array}$ & $\begin{array}{c}1.143 \\
(0.000)\end{array}$ \\
\hline \multirow[t]{4}{*}{ By liquidity } & Very high (Sight Accounts) & 0.588 & -0.111 & -0.116 & $0.930 * \star *$ & 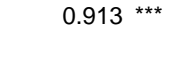 & $\begin{array}{c}0.831 \\
(0.000)\end{array}$ & $\begin{array}{c}1.091 \\
(0.000)\end{array}$ \\
\hline & Medium & 0.643 & -0.107 & -0.214 & $0.209 * * *$ & $0.434 * * *$ & $\begin{array}{c}0.120 \\
(0.000)\end{array}$ & $\begin{array}{c}0.012 \\
(0.000)\end{array}$ \\
\hline & Low & 0.515 & -0.037 & 0.068 & $0.183 * * *$ & $0.258 * * *$ & $\begin{array}{c}0.146 \\
(0.000)\end{array}$ & $\begin{array}{c}0.116 \\
(0.000)\end{array}$ \\
\hline & High & 0.558 & -0.150 & -0.068 & $0.146 * * *$ & 0.191 *** & $\begin{array}{c}0.109 \\
(0.000)\end{array}$ & $\begin{array}{c}0.137 \\
(0.000)\end{array}$ \\
\hline \multirow[t]{9}{*}{ By type of product } & Receivable & 0.521 & -0.011 & 0.054 & $0.637 * * *$ & $0.408 * \star \star$ & $\begin{array}{c}0.719 \\
(0.000)\end{array}$ & $\begin{array}{c}0.925 \\
(0.000)\end{array}$ \\
\hline & Credit Line & 0.501 & -0.041 & 0.024 & $0.768 * \star *$ & $0.438 * \star \star$ & $\begin{array}{c}0.813 \\
(0.000)\end{array}$ & $\begin{array}{c}1.214 \\
(0.000)\end{array}$ \\
\hline & Personal & 0.521 & -0.006 & 0.092 & $0.895 * * *$ & $0.509 * \star \star$ & $\begin{array}{c}0.861 \\
(0.000)\end{array}$ & $\begin{array}{c}1.540 \\
(0.000)\end{array}$ \\
\hline & Mortgages & 0.593 & 0.074 & 0.141 & $0.533 * \star \star$ & $0.110 * \star *$ & $\begin{array}{c}0.543 \\
(0.000)\end{array}$ & $\begin{array}{c}1.143 \\
(0.000)\end{array}$ \\
\hline & Variable & 0.453 & 0.022 & 0.194 & $0.296 * \star *$ & 0.168 *** & $\begin{array}{c}0.223 \\
(0.000)\end{array}$ & $\begin{array}{c}0.546 \\
(0.000)\end{array}$ \\
\hline & Deposit & 0.593 & -0.063 & -0.068 & $0.215 * * *$ & $0.313 * * *$ & $\begin{array}{c}0.175 \\
(0.000)\end{array}$ & $\begin{array}{c}0.132 \\
(0.000)\end{array}$ \\
\hline & Repo & 0.493 & -0.115 & 0.026 & $0.119 * \star *$ & $0.238 * \star \star *$ & $\begin{array}{c}0.055 \\
(0.000)\end{array}$ & $\begin{array}{c}0.023 \\
(0.000)\end{array}$ \\
\hline & Current & 0.610 & -0.044 & -0.086 & $0.602 * * *$ & $0.535 * \star \star$ & $\begin{array}{c}0.585 \\
(0.000)\end{array}$ & $\begin{array}{c}0.721 \\
(0.000)\end{array}$ \\
\hline & Saving & 0.562 & -0.191 & -0.152 & $1.318 * \star \star$ & $1.351 * \star *$ & $\begin{array}{c}1.126 \\
(0.000)\end{array}$ & $\begin{array}{c}1.538 \\
(0.000)\end{array}$ \\
\hline
\end{tabular}

Notes.- $\left({ }^{* * *}\right)=$ Significant at $\left.1 \% .{ }^{*}\right)=$ Significant at $5 \% . \quad(*)=$ Significant at $1 \%$. Stat
a The asterisks refer to the test of significance of the first-period average intercept.

beriod with respect to that of the previous period. 
Table 7. Estimated slope coefficients of partial adjustment model for mark up of interest rates on loan and deposits.

Dependent variable is $\ln r_{\mathrm{ijt}}-\ln \mathrm{i}_{\mathrm{i}}$ for loan products and $\ln \mathrm{i}-\ln \mathrm{r}_{\mathrm{ijt}}$ for deposit products, where $\mathrm{r}_{\mathrm{ijt}}$ is the interest rate of Bank $j$ on Product $i$ at Time $t$ $i$ is the opportunity cost for loans and $i$ is the opportunity cost for deposits.

The Estimated Equation is $\mathrm{Y}_{\mathrm{jt}}=\delta+\alpha \mathrm{Y}_{\mathrm{jt}-1}+\gamma_{1} \mathrm{D}_{1} \mathrm{Y}_{\mathrm{jt}-1}+\gamma_{2} \mathrm{D}_{2} \mathrm{Y}_{\mathrm{jt}-1}+$ Year Dummies $+\eta_{\mathrm{j}}+\varepsilon_{\mathrm{ijt}}$

Coefficients reported have been obtained applying the Arellano \& Bond estimation technique for each product, using up to four lags of the dependent variable as instruments.

\begin{tabular}{|c|c|c|c|c|}
\hline & $\alpha$ & $\gamma_{1}$ & $\gamma_{2}$ & $\begin{array}{l}\text { P-values of } 2^{\text {nd }} \text { order } \\
\text { autocorrelation statistic }\end{array}$ \\
\hline RECEIVABLEless3months & 0.916 *** & $-0.289 * \star \star$ & $-0.333^{* \star *}$ & 0.063 \\
\hline RECEIVABLE3months-1year & $0.804 * * *$ & -0.128 * & -0.067 & 0.169 \\
\hline RECEIVABLE1year-3years & $0.480 * \star \star$ & $-0.199 * \star \star$ & -0.110 * & 0.393 \\
\hline CREDITLINEless3months & $0.585 * * *$ & $-0.162 *$ & 0.028 & 0.310 \\
\hline CREDITLINE3months-1year & $0.638 * * *$ & $-0.137 * \star$ & $-0.208 * \star *$ & 0.823 \\
\hline CREDITLINE1year-3years & $0.934 * * *$ & $-0.166 * \star$ & $-0.240 * *$ & 0.761 \\
\hline CREDITLINEmore3years & $0.731 * * *$ & -0.164 & -0.200 & 0.804 \\
\hline PERSONALless3months & $0.725 * \star *$ & $-0.269 * * *$ & $-0.155 *$ & 0.143 \\
\hline PERSONAL3months-1year & $0.886 * * *$ & $-0.321 *$ & $-0.463 * *$ & 0.108 \\
\hline PERSONAL1year-3years & $1.005 * * *$ & $-0.205 * *$ & $-0.260 * * *$ & 0.999 \\
\hline PERSONALmore3years & $0.961 * * *$ & -0.119 & -0.098 & 0.195 \\
\hline MORTGAGEmore3years & $0.682 * * *$ & 0.132 & $-0.420 * * *$ & 0.897 \\
\hline VARIABLEless1month & $0.743 * \star \star$ & $-0.306 * *$ & $-0.449 * *$ & 0.105 \\
\hline VARIABLE1month-3months & $0.693 * * *$ & $-0.359 * \star *$ & $-0.452 * * *$ & 0.115 \\
\hline VARIABLEmore3months & $0.631 * * *$ & $-0.195 *$ & -0.098 & 0.741 \\
\hline DEPOSITSless3months & $0.616 * \star *$ & $-0.183 * \star *$ & $-0.135 * *$ & 0.686 \\
\hline DEPOSITS3months-6months & $0.670 * * *$ & $-0.247 * \star \star$ & 0.011 & 0.342 \\
\hline DEPOSITS6months-1year & $0.621 * * *$ & $-0.281 * * *$ & $-0.163 * * *$ & 0.348 \\
\hline DEPOSITS1year-2years & $0.568 * * *$ & -0.010 & 0.062 & 0.107 \\
\hline DEPOSITSmore2years & $0.455 * * *$ & 0.117 * & -0.131 & 0.860 \\
\hline REPOless3months & $0.511 * * \star$ & -0.124 * & -0.013 & 0.624 \\
\hline REPO3months-6months & $0.435 * * *$ & -0.177 * & -0.095 & 0.515 \\
\hline REPO6months-1year & $0.424 * * *$ & -0.087 & -0.220 * & 0.998 \\
\hline CURRENT & $0.610 * \star *$ & -0.044 & -0.086 & 0.821 \\
\hline SAVINGS & $0.562 * * *$ & $-0.191 * \star *$ & $-0.152 * * *$ & 0.880 \\
\hline
\end{tabular}

The null hypothesis of $\alpha=1$ cannot be rejected at $p$ values of $10 \%$ for Credit Lines 1 year-3 years (first period) and for Personalloans 3 months-1 year

(first period), 1 year -3 years (first period), more 3 years (all periods). 
Table 8. Summary of slope coefficients $\alpha$ and long term mark up of interest rates on loans and deposits.

Slope coefficients are weighted averages of those in Table 8 . Long term mark up are averages of $\delta /(1-\alpha)$, also from Table 8.

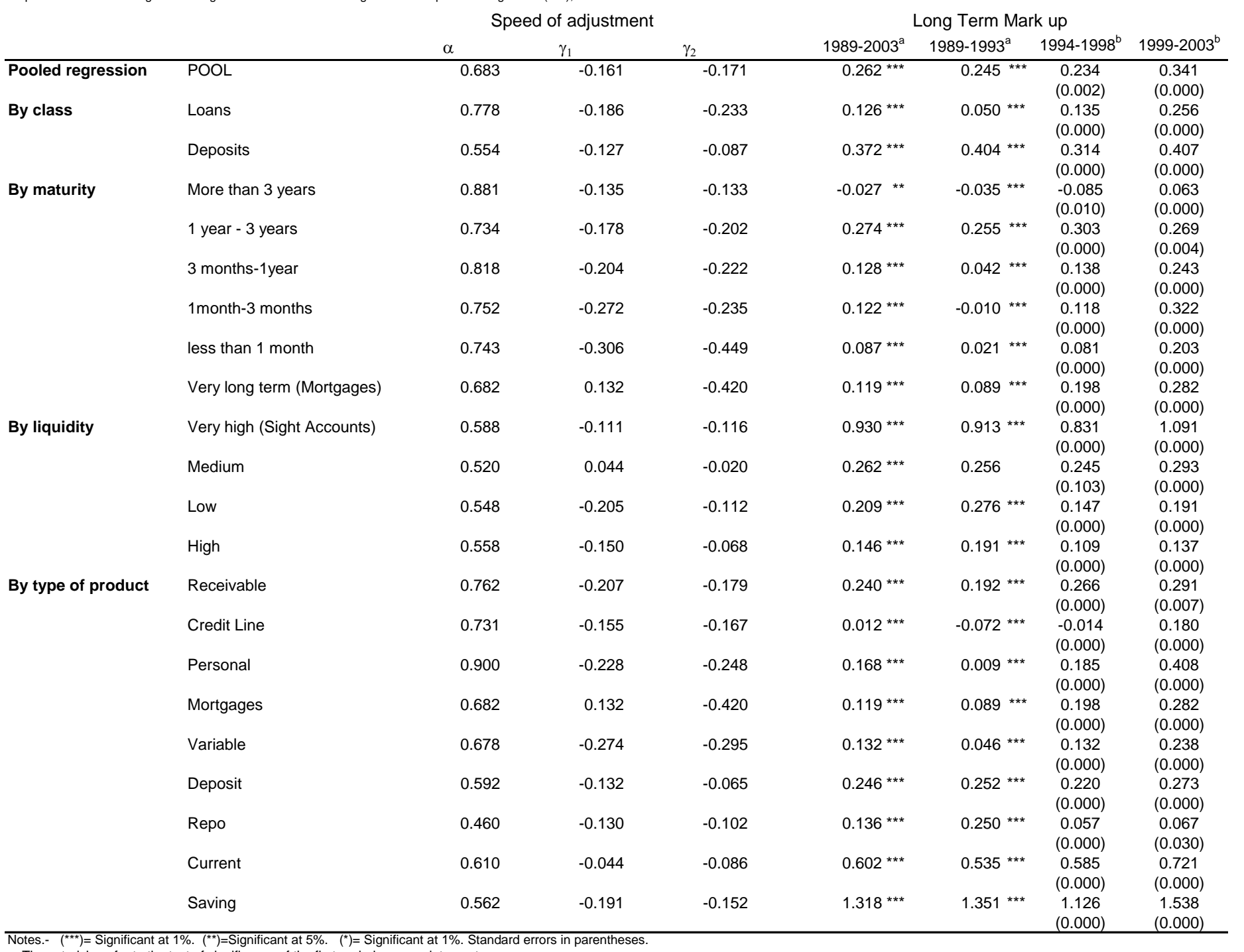

Notes.-
a The asterisks refer to the test of significicance of the first-period averant at $1 \%$.

a The asterisks refer to the test of significance of the first-period average intercept.
$\mathrm{b}$ Figures in parentheses are the p-values obtained from the test of equality of the average intercept in the period with respect to that of the previous period. 
Figure 1: Interest Rates of Spanish Banks

Selected Bank Products, 1989-2003. In Percentage

Loans

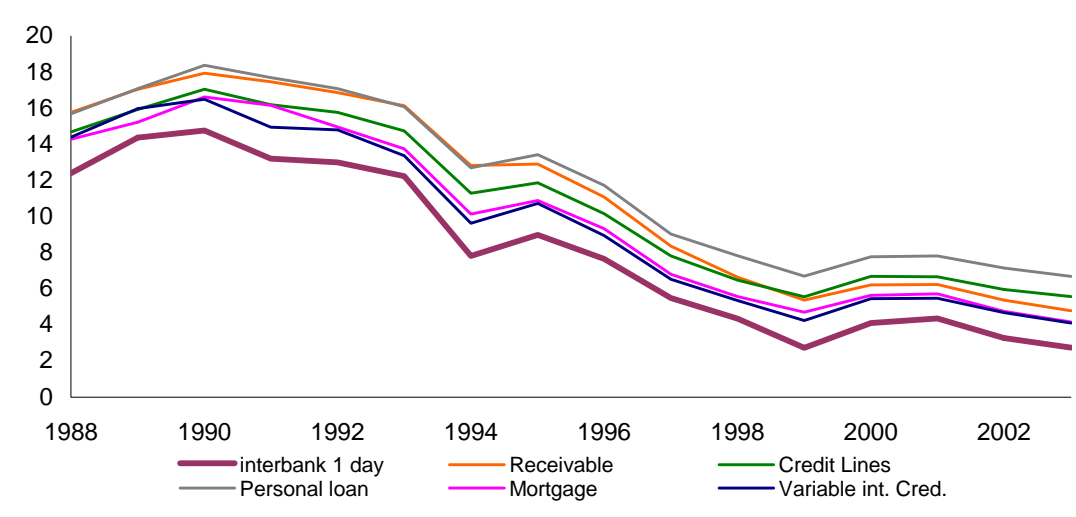

Deposits

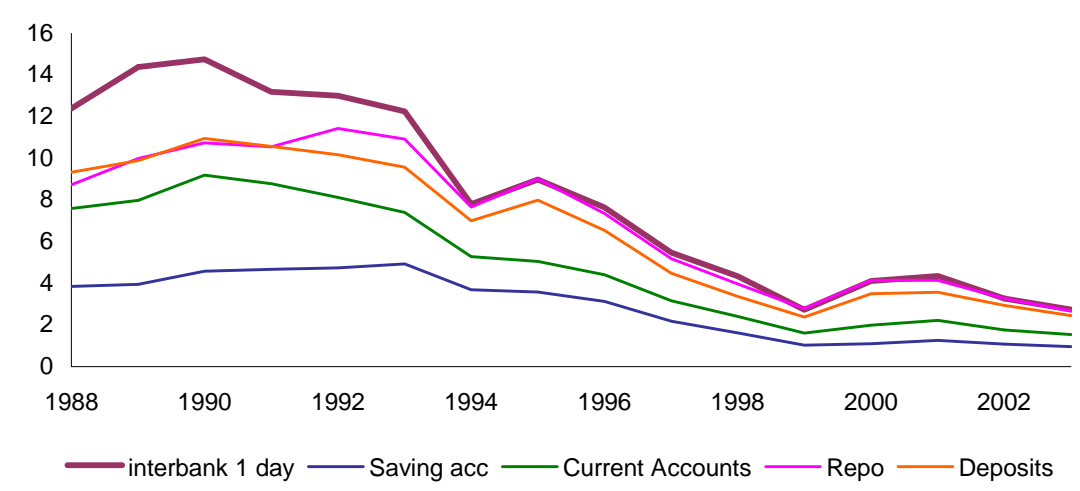


Figure 2. Coefficient of Variation of Interest Rates of Spanish Banks, selected Bank

Products. 1989-2003

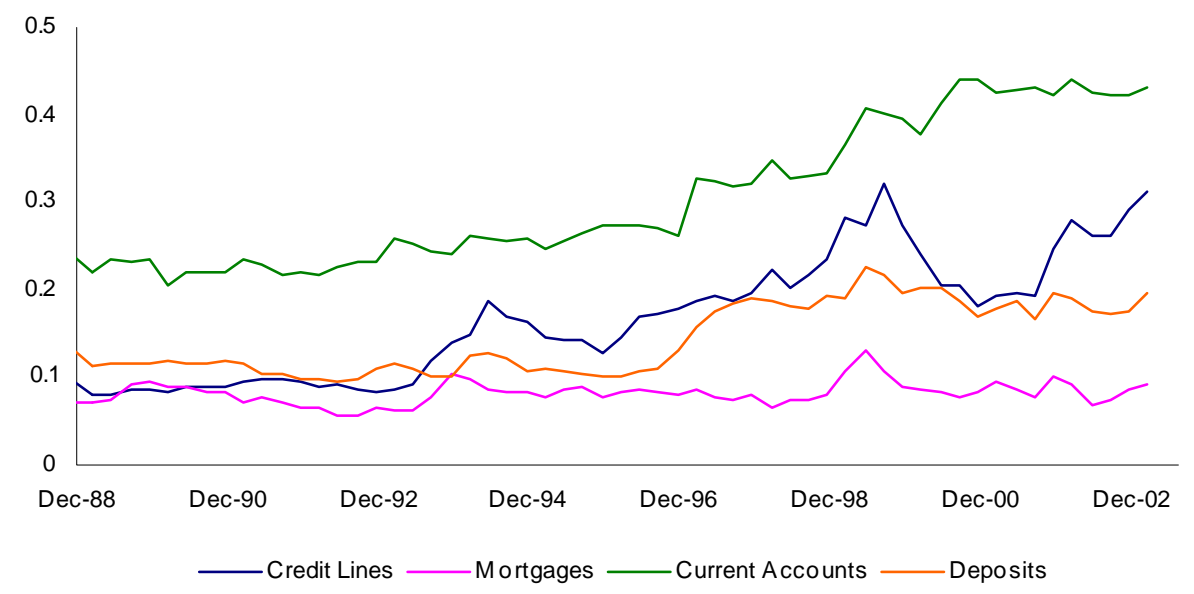


Figure 3. Histogram of relative interest rate range for all bank products

Difference between the $90^{\text {th }}$ and $10^{\text {th }}$ percentiles, divided by the Average Interest rate of the Respective Bank Product.

(1989-2003)

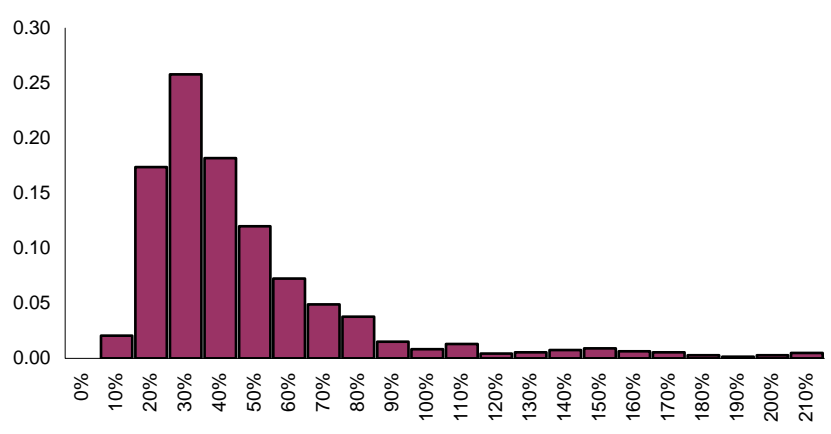

(1994-1998)

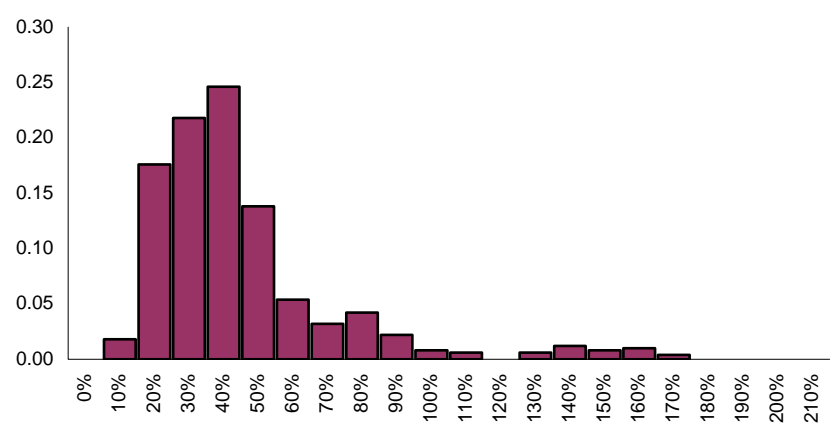

(1989-1993)

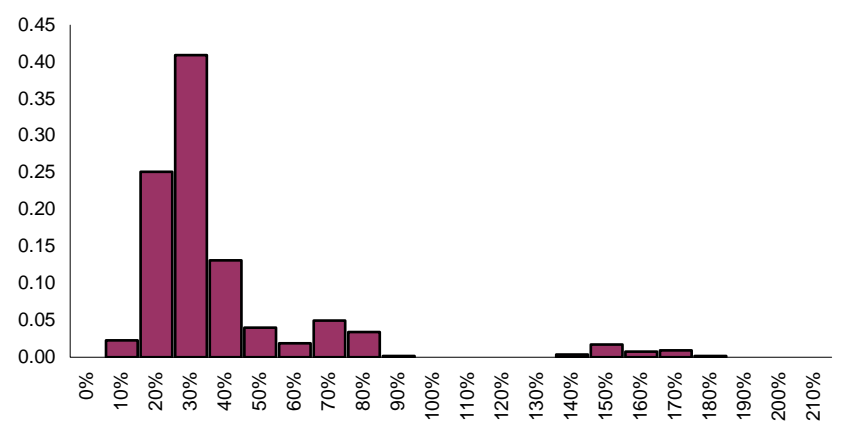

(1999-2003)

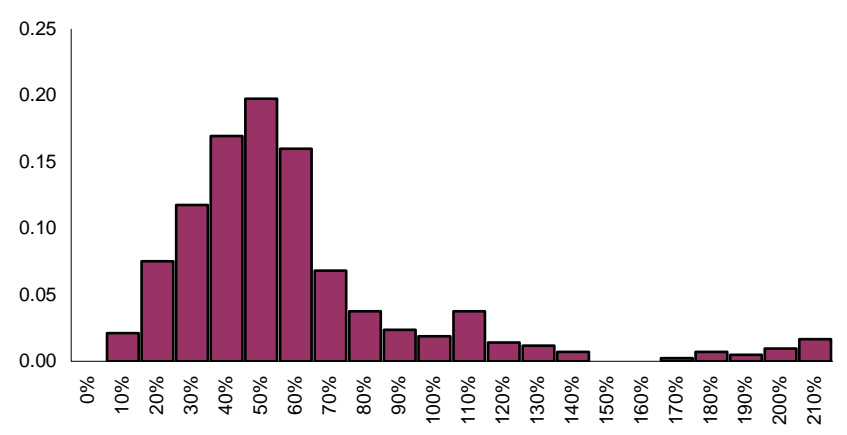


Figure 4. Opportunity Cost of Loans Relative to One-Day Interbank Interest

Rate. 1989-2003

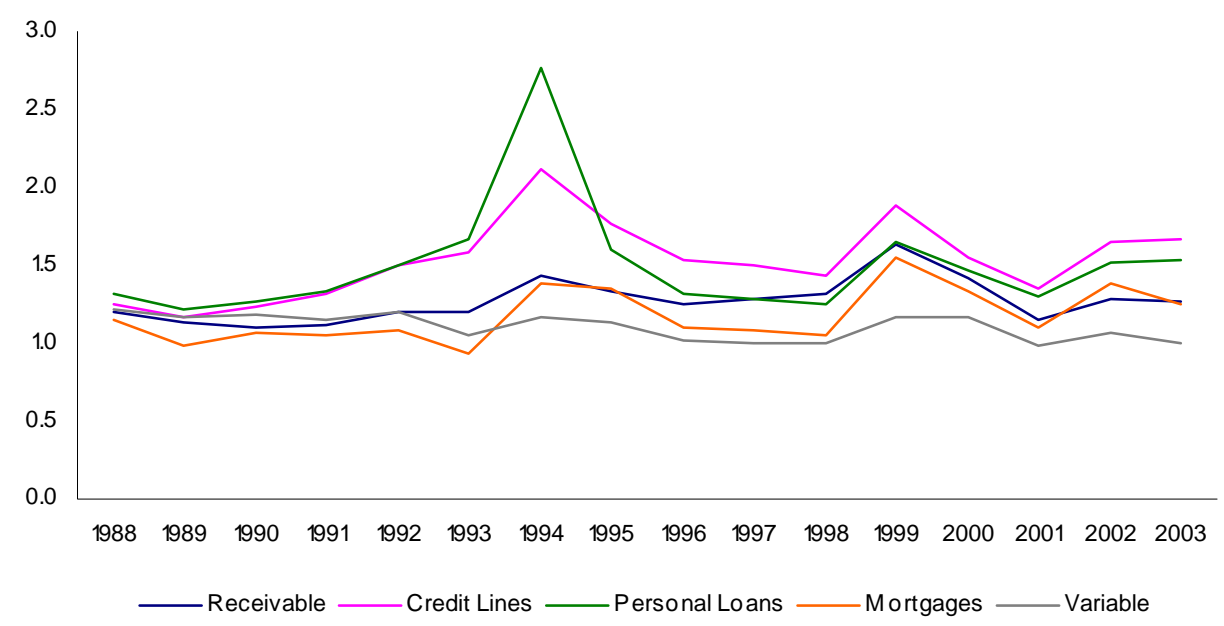




\section{BANCO DE ESPAÑA PUBLICATIONS}

\section{WORKING PAPERS ${ }^{1}$}

0401 ROBERTO BLANCO, SIMON BRENNAN AND IAN W. MARSH: An empirical analysis of the dynamic relationship between investment grade bonds and credit default swaps.

0402 ENRIQUE ALBEROLA AND LUIS MOLINA: What does really discipline fiscal policy in emerging markets? The role and dynamics of exchange rate regimes.

0403 PABLO BURRIEL-LLOMBART: An economic analysis of education externalities in the matching process of UK regions (1992-1999).

0404 FABIO CANOVA, MATTEO CICCARELLI AND EVA ORTEGA: Similarities and convergence in G-7 cycles.

0405 ENRIQUE ALBEROLA, HUMBERTO LÓPEZ AND LUIS SERVÉN: Tango with the gringo: the hard peg and real misalignment in Argentina.

0406 ANA BUISÁN, JUAN CARLOS CABALLERO AND NOELIA JIMÉNEZ: Determinación de las exportaciones de manufacturas en los países de la UEM a partir de un modelo de oferta-demanda.

0407 VÍTOR GASPAR, GABRIEL PÉREZ QUIRÓS AND HUGO RODRÍGUEZ MENDIZÁBAL: Interest rate determination in the interbank market.

0408 MÁXIMO CAMACHO, GABRIEL PÉREZ-QUIRÓS AND LORENA SAIZ: Are European business cycles close enough to be just one?

0409 JAVIER ANDRÉS, J. DAVID LÓPEZ-SALIDO AND EDWARD NELSON: Tobin's imperfect assets substitution in optimizing general equilibrium.

0410 A. BUISÁN, J. C. CABALLERO, J. M. CAMPA AND N. JIMÉNEZ: La importancia de la histéresis en las exportaciones de manufacturas de los países de la UEM.

0411 ANDREW BENITO, FRANCISCO JAVIER DELGADO AND JORGE MARTÍNEZ PAGÉS: A synthetic indicator of financial pressure for Spanish firms.

0412 JAVIER DELGADO, IGNACIO HERNANDO AND MARÍA J. NIETO: Do European primarily Internet banks show scale and experience efficiencies?

0413 ÁNGEL ESTRADA, JOSÉ LUIS FERNÁNDEZ, ESTHER MORAL AND ANA V. REGIL: A quarterly macroeconometric model of the Spanish economy.

0414 GABRIEL JIMÉNEZ AND JESÚS SAURINA: Collateral, type of lender and relationship banking as determinants of credit risk.

0415 MIGUEL CASARES: On monetary policy rules for the euro area.

0416 MARTA MANRIQUE SIMÓN AND JOSÉ MANUEL MARQUÉS SEVILLANO: An empirical approximation of the natural rate of interest and potential growth. (The Spanish original of this publication has the same number).

0417 REGINA KAISER AND AGUSTíN MARAVALL: Combining filter design with model-based filtering (with an application to business-cycle estimation).

0418 JÉRÔME HENRY, PABLO HERNÁNDEZ DE COS AND SANDRO MOMIGLIANO: The short-term impact of government budgets on prices: evidence from macroeconometric models.

0419 PILAR BENGOECHEA AND GABRIEL PÉREZ-QUIRÓS: A useful tool to identify recessions in the euro area.

0420 GABRIEL JIMÉNEZ, VICENTE SALAS AND JESÚS SAURINA: Determinants of collateral.

0421 CARMEN MARTÍNEZ-CARRASCAL AND ANA DEL RÍO: Household borrowing and consumption in Spain: A VECM approach.

0422 LUIS J. ÁLVAREZ AND IGNACIO HERNANDO: Price setting behaviour in Spain: Stylised facts using consumer price micro data.

0423 JUAN CARLOS BERGANZA AND ALICIA GARCÍA-HERRERO: What makes balance sheet effects detrimental for the country risk premium?

0501 ÓSCAR J. ARCE: The fiscal theory of the price level: a narrow theory for non-fiat money.

0502 ROBERT-PAUL BERBEN, ALBERTO LOCARNO, JULIAN MORGAN AND JAVIER VALLÉS: Cross-country differences in monetary policy transmission.

0503 ÁNGEL ESTRADA AND J. DAVID LÓPEZ-SALIDO: Sectoral mark-up dynamics in Spain.

0504 FRANCISCO ALONSO, ROBERTO BLANCO AND GONZALO RUBIO: Testing the forecasting performance of Ibex 35 option-implied risk-neutral densities.

1. Previously published Working Papers are listed in the Banco de España publications calalogue. 
0505 ALICIA GARCÍA-HERRERO AND ÁLVARO ORTIZ: The role of global risk aversion in explaining Latin American sovereign spreads.

0506 ALFREDO MARTíN, JESÚS SAURINA AND VICENTE SALAS: Interest rate dispersion in deposit and loan markets.

0507 MÁXIMO CAMACHO AND GABRIEL PÉREZ-QUIRÓS: Jump-and-rest effect of U.S. business cycles.

0508 LUIS J. ÁLVAREZ, PABLO BURRIEL AND IGNACIO HERNANDO: Do decreasing hazard functions for price changes make any sense?

0509 ÁNGEL DE LA FUENTE AND JUAN F. JIMENO: The private and fiscal returns to schooling and the effect of public policies on private incentives to invest in education: a general framework and some results for the EU.

0510 JUAN J. DOLADO, MARCEL JANSEN AND JUAN F. JIMENO: Dual employment protection legislation: a framework for analysis.

0511 ANA DEL RÍO AND GARRY YOUNG: The determinants of unsecured borrowing: evidence from the British household panel survey.

0512 ANA DEL RÍO AND GARRY YOUNG: The impact of unsecured debt on financial distress among British households.

0513 ADELA LUQUE: Skill mix and technology in Spain: evidence from firm-level data.

0514 J. DAVID LÓPEZ-SALIDO, FERNANDO RESTOY AND JAVIER VALLÉS: Inflation differentials in EMU: The Spanish case.

0515 ISAAC ALFON, ISABEL ARGIMÓN AND PATRICIA BASCUÑANA-AMBRÓS: How individual capital requirements affect capital ratios in UK banks and building societies.

0516 JOSÉ MANUEL CAMPA AND IGNACIO HERNANDO: M\&As performance in the European financial industry.

0517 ALICIA GARCÍA-HERRERO AND DANIEL SANTABÁRBARA: Does China have an impact on foreign direct investment to Latin America?

0518 MAXIMO CAMACHO, GABRIEL PEREZ-QUIROS AND LORENA SAIZ: Do European business cycles look like one?

0519 DANIEL PÉREZ, VICENTE SALAS-FUMÁS AND JESÚS SAURINA: Banking integration in Europe.

0520 JORDI GALÍ, MARK GERTLER AND J. DAVID LÓPEZ-SALIDO: Robustness of the estimates of the hybrid New Keynesian Phillips curve.

0521 JAVIER ANDRÉS, J. DAVID LÓPEZ-SALIDO AND EDWARD NELSON: Sticky-price models and the natural rate hypothesis.

0522 OLYMPIA BOVER: Wealth effects on consumption: microeconometric estimates from the Spanish survey of household finances.

0523 ENRIQUE ALBEROLA, LUIS MOLINA AND DANIEL NAVIA: Say you fix, enjoy and relax: the deleterious effect of peg announcements on fiscal discipline.

0524 AGUSTÍN MARAVALL: An application of the TRAMO SEATS automatic procedure; direct versus indirect adjustment.

0525 ALICIA GARCÍA-HERRERO AND MARÍA SOLEDAD MARTíNEZ-PERÍA: The mix of international banks' foreign claims: determinants and implications for financial stability.

0526 J. IGNACIO GARCÍA-PÉREZ AND JUAN F. JIMENO: Public sector wage gaps in Spanish regions.

0527 LUIS J. ÁLVAREZ, PABLO BURRIEL AND IGNACIO HERNANDO: Price setting behaviour in Spain: evidence from micro PPI data.

0528 EMMANUEL DHYNE, LUIS J. ÁLVAREZ, HERVÉ LE BIHAN, GIOVANNI VERONESE, DANIEL DIAS, JOHANNES HOFFMANN, NICOLE JONKER, PATRICK LÜNNEMANN, FABIO RUMLER AND JOUKO VILMUNEN: Price setting in the euro area: some stylized facts from individual consumer price data.

0529 TERESA SASTRE AND JOSÉ LUIS FERNÁNDEZ-SÁNCHEZ: Un modelo empírico de las decisiones de gasto de las familias españolas.

0530 ALFREDO MARTÍN-OLIVER, VICENTE SALAS-FUMÁS AND JESÚS SAURINA: A test of the law of one price in retail banking.

\begin{tabular}{|c|c|}
\hline & Unidad de Publicaciones \\
BANCODEESPAÑNA & Alcalá, 522; 28027 Madrid \\
& Telephone +34 91 338 6363. Fax +34913386488 \\
e-mail: Publicaciones@bde.es \\
www.bde.es
\end{tabular}




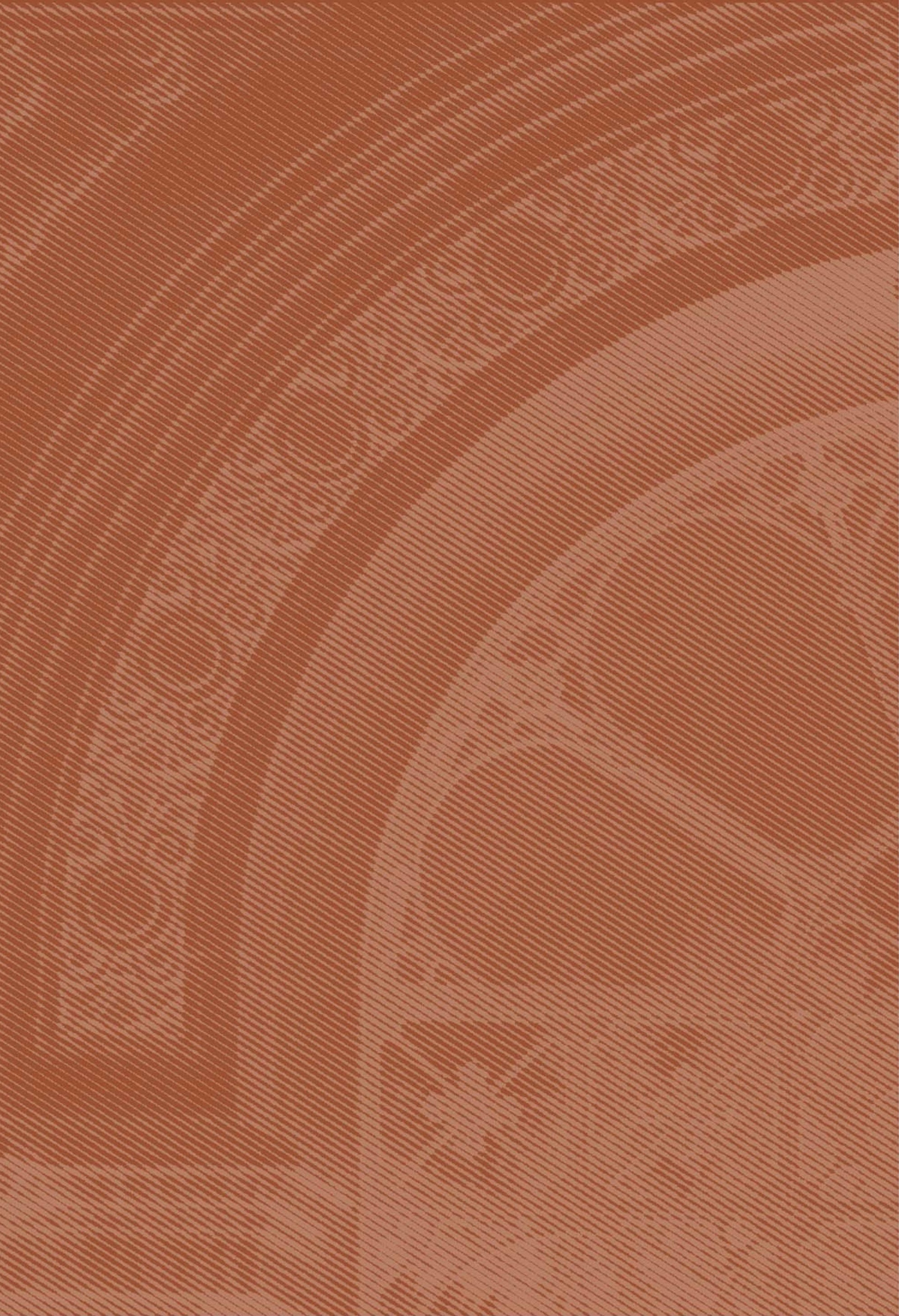

